\title{
Multinationals and Linkages: An Empirical Investigation
}

\author{
Laura Alfaro* \\ Harvard Business School
}

\author{
Andrés Rodríguez-Clare** \\ Inter-American Development Bank
}

November 2003

\begin{abstract}
Several recent papers have used plant-level data and panel econometric techniques to carefully explore the existence FDI externalities. One conclusion that emerges from this literature is that it is difficult to find evidence of positive externalities from multinationals to local firms in the same sector (horizontal externalities). In fact, many studies find evidence of negative horizontal externalities arising from multinational activity while confirming the existence of positive externalities from multinationals to local firms in upstream industries (vertical externalities). In this paper we explore the channels through which these positive and negative externalities may be materializing, focusing on the role of backward linkages. In particular, we criticize the common usage of the domestic sourcing coefficient as an indicator of a firm's linkage potential and propose an alternative, theoretically derived indicator. We then use plant-level data from several Latin American countries to compare multinationals' linkage potential to that of domestic firms. We find that multinational's linkage potential in Brazil, Chile and Venezuela is higher than for domestic firms. For Mexico, we cannot reject the hypothesis that foreign and local firms have similar linkage potential. Finally, we discuss the relationship between this finding and the conclusions that emerge from the recent empirical literature.
\end{abstract}

JEL Classification: F23, O19, O24

Keywords: Foreign Direct Investment, Multinational Firms, Linkages, Spillovers, Economic Development.

* Laura Alfaro. Harvard Business School, Morgan 263, Boston Ma 02163, (lalfaro@hbs.edu).

**Andrés Rodríguez-Clare. Research Department, Inter-American Development Bank (andresro@iadb.org) We would like to thank our discussants Gordon H. Hanson and Claudio Bravo-Ortega, as well as Ernesto Stein, Ugo Panizza, Holger Gorg and participants at the $8^{\text {th }}$ Economía Panel meeting, Kennedy School's LIEP, Kellog Institute for International Studies at Notre Dame and the Econnet Seminar at the IADB for valuable comments. Manuel Pacheco and Luis Rivera provided excellent research assistance. We further thank Ernesto López-Córdova, Mauricio Mesquita Moreira, Juan Blyde and Alejandro Micco for kindly helping with the data from Mexico, Brazil, Venezuela and Chile, respectively. 


\section{1 - Introduction}

Policy makers and academics often argue that foreign direct investment (FDI) can be a source of valuable productivity externalities for developing countries. ${ }^{1}$ Prominent among the mechanisms often highlighted for these externalities are knowledge spillovers and "linkages" from multinationals (MNCs) to domestic firms in host countries. In pursuit of such benefits, over the last two decades governments in both developed and developing countries have not only reduced barriers to FDI but have also offered special incentives to attract foreign firms and foster relationships between MNCs and local firms (specially suppliers). Surprisingly, however, the empirical literature has not been able to confirm the existence of positive externalities from FDI to host countries. ${ }^{2}$ Thus, there appears to be a significant gap between the consensus among practitioners and the empirical literature regarding the importance of positive FDI externalities.

As mentioned, many countries offer special incentives to FDI. ${ }^{3}$ Policies to promote FDI take a variety of forms. In general, incentives fall into two categories: fiscal incentives, such as tax holidays and lower taxes for foreign investors; and financial incentives, such as government grants, credits at subsidized rates, government equity participation and government insurance at preferential rates. Other incentives can include subsidized dedicated infrastructure, subsidized services, contract preferences or foreign exchange privileges and even monopoly rights. In 1998, 103 countries offered tax concessions to foreign companies that set up production or administrative facilities within their border (Hanson, 2001).

In popular discussions it is sometimes argued that this kind of policy is justified as a way to generate employment, but - of course - in economies under full employment

\footnotetext{
${ }^{1}$ The scholarly literature on foreign direct investment is vast and has been surveyed many times. For recent surveys see Markusen (1995), Caves (1996), Blomstrom and Kokko (1998), Hanson (2001) and Lipsey (2002).

${ }^{2}$ In a recent survey of empirical work, Hanson (2001) argues that there is weak evidence that FDI generates positive externalities for host countries. In a review of micro data on externalities from foreign owned to domestically owned firms, Gorg and Greenwood (2002) conclude that the effects are mostly negative. Lipsey (2002) takes a more favorable view from reviewing the micro literature while concluding that in general the macro empirical research indicates that the size of inward FDI stocks or flows relative to GDP is not related in a consistent way with growth.

${ }^{3}$ On the debate behind incentives to FDI, see Wells and Wint (2000), Hanson (2001) and Blomstrom and Kokko (2003).
} 
this is not a valid argument. Even if there is unemployment, it is not clear that more investment will solve the problem; this would depend on the causes and nature of unemployment. A more sophisticated argument is that FDI incentives are valid as a way to increase the capital stock and thereby allow wages to increase. For this to be cost efficient, however, the rate of return to capital in the host country would have to be higher than in source countries. But if this were the case, then the subsidy would not be necessary. A related and valid reasoning is that FDI incentives are justified as part of an optimal tax policy, if it is believed that the investment elasticity to taxes is higher for FDI than for national investment. The problem, of course, is that this is ultimately selfdefeating, because countries would compete away the rents and pass them on to multinationals.

In this paper we focus on productivity externalities arising from multinationals to domestic firms in the host country as a possibly valid reason for subsidizing FDI. Several recent papers have used plant-level data and panel econometric techniques to carefully explore the existence of this type of externalities. One conclusion that emerges from this literature is that it is difficult to find evidence of positive externalities from multinationals to local firms in the same sector (horizontal externalities). In fact, many studies find evidence of negative horizontal externalities arising from multinational activity while confirming the existence of positive externalities from multinationals to local firms in upstream industries (vertical externalities). In this paper we explore the channels through which these positive and negative externalities may materialize, and focus on the role of backward linkages, which have not received enough rigorous theoretical and empirical attention.

Under certain conditions (benefits of specialization, increasing returns and transportation costs) an increase in demand for specialized inputs would lead to the local production of new types of these inputs and this would bring positive externalities to other domestic firms that use those inputs. This mechanism, however, has been called into question because of the general finding that the share of inputs bought domestically by MNCs is lower than for local firms. Many papers have interpreted this finding as implying that MNCs generate fewer linkages than domestic firms. We will argue that the share of inputs bought domestically is not a valid indicator of the linkage that MNCs can 
generate. Instead, based on the model of linkages developed by Rodríguez-Clare (1996), we propose an alternative indicator for the linkages that a firm can generate and then proceed to calculate it for several countries in Latin America.

The alternative indicator of linkages we propose is the ratio of the value of inputs bought domestically to the total workers hired by the firm. Based on this definition, we explore the validity of the claims that have been made in the literature regarding linkages across different types of firms. Using plant-level data from Brazil (1997 to 2000), Venezuela (1995 to 2000), Mexico (1993 to 2000) and Chile (1987 to 1999), we test for differences in the linkage coefficient between foreign and domestic firms. In all countries analyzed, and consistent with previous findings in the literature, the share of domestic inputs sourced domestically is lower for foreign firms. In contrast, using our proposed indicator, we find that foreign firms have higher linkage coefficient in Brazil, Chile and Venezuela. For Mexico, we cannot reject the hypothesis that foreign and domestic firms have the same linkage potential.

Thus, our results suggest that some of the general notions in the literature may be due to using linkage measures that are not properly derived from theory. It is likely that although multinationals do source a lower percentage of their inputs domestically, they also use more inputs in relation to the workers they hire. As a result, they do not necessarily generate weaker linkages than domestic firms. For linkages to be meaningful, however, it must be that inputs are non-tradable (or, more generally, have high costs associated with importing them, relative to domestic procurement) and produced with increasing returns to scale. ${ }^{4}$ The approach we follow here can be interpreted as establishing upper bounds on the linkages that can be generated by different firms.

The rest of the paper is organized as follows. Section 2 reviews the empirical literature on FDI spillovers. Section 3 presents a preliminary discussion on backward linkages. Section 4 develops the model. Section 5 describes the data for Brazil, Chile, Mexico and Venezuela and presents the main results. Section 6 discusses the main findings in relation to the literature. The last section concludes.

\footnotetext{
${ }^{4}$ This point was made originally by Hirschman (1958), and also formalized among others by RodríguezClare (1996).
} 


\section{2 - A view of the recent empirical literature}

What is the empirical evidence regarding spillovers and linkages? ${ }^{5}$ One robust finding is that MNCs tend to have higher productivity than domestic firms in the same sector (Haddad and Harrison, 1993; Blomstrom and Wolff, 1994; Kokko, Zejan and Tainsini, 2001). Under these circumstances, FDI would lead to a higher GDP. If MNCs paid market wages, the increased GDP would be completely captured by MNCs, and hence national welfare would not increase. There is ample evidence, however, that MNCs do pay above market wages (Blomstom, 1983; Haddad and Harrison, 1993; Aitken, Harrison and Lipsey, 1997; Girma, Greenaway and Wakelin, 1999; Lipsey and Sjoholm, $2001,2002)$ so that it is very likely that some of their higher productivity is shared with nationals. This could justify some kind of incentives for MNCs.

Of potentially much more importance is the possibility that MNCs have a positive impact on the productivity levels of local firms. Most studies look for the presence of such productivity externalities without trying to understand the mechanism through which they occur. In other words, empirical studies have focused on finding indirect evidence of externalities by exploring whether increases in the presence of MNCs in a country or sector are associated with increases in local firms' productivity in that country or sector or in upstream sectors.

The empirical evidence on whether FDI generates positive externalities for host countries is ambiguous, although the evidence for developing countries is more consistently pessimistic (see Table 1 for an overview of the evolution of this literature). Using careful econometric techniques, the literature not only has failed to detect the presence of positive productivity externalities for developing countries, but actually has found evidence of negative externalities (see Haddad and Harrison, 1993; Aitken and Harrison, 1999). ${ }^{6}$

\footnotetext{
${ }^{5}$ See Gorg and Greenaway (2002) and Lipsey (2002) for recent overviews of the literature.

${ }^{6}$ The evidence for industrialized countries tends to be more positive. Haskel, Pereira and Slaughter (2002) find positive benefits from foreign to local firms in a panel data set of firms in the UK; Gorg and Strobl (2002) find that foreign presence reduces exit and encourages entry by domestic-owned firms in the hightech sector in Ireland.
} 
A first generation of industry level (cross-section) studies generally found a positive correlation between foreign presence and sectoral productivity (for example, the pioneering work of Caves (1974) finds positive FDI spillovers in Australia; Blomstrom (1986) and Blomstrom and Wolff (1994) find positive effects for Mexico; and Sjoholm (1999) for Indonesia). At the macroeconomic level, cross-section empirical work by Borensztein, De Gregorio, and Lee (1998) and Alfaro, Chandra, Kalemli-Ozcan and Sayek (2003) finds little support that FDI has an exogenous positive effect on economic growth. However, their evidence suggests that local conditions, such as the level of education and the development of local financial markets play an important role in allowing the positive effects of FDI to materialize. For example, in a widely cited paper in the literature, Borensztein et al. (1998), using a dataset of FDI flows from industrialized countries to sixty-nine developing countries find that FDI is an important vehicle for transferring technology and higher growth only when the host country has a minimum threshold of human capital. ${ }^{7}$

As Aitken and Harrison (1999) note, however, cross-section studies of this nature are subject to a critical identification problem. ${ }^{8}$ At the micro level, foreign firms may be located in high productivity industries as opposed to causing productivity externalities. At the macro level, high growth countries may attract more FDI as opposed to FDI causing this high growth. If this is the case, the coefficients on cross-section estimates are likely to overstate the positive impact of foreign investment. As a result, one could find evidence of positive externalities from foreign investment where no externalities occur.

At the macro level, Carkovic and Levine's (2002) work, for example, casts doubt on the findings on growth and FDI. Using the Generalized Method of Moments (GMM) estimator designed by Arrellano and Bover (1995) to account for simultaneity bias and country-specific effects, they find that the exogenous component of FDI does not exert a robust positive influence on growth. At the micro level, the work of Aitken and Harrison (1999), using a panel data set of Venezuelan plants, confirms that differences in

\footnotetext{
${ }^{7}$ Likewise, Xu (2000) using data on U.S. MNCs finds that a country needs to reach a minimum human capital threshold in order to benefit from the technology transfer from MNCs, and that most developing countries do not meet this threshold.

${ }^{8}$ Since cross-sectional studies aggregated at the sector level fail to control for time invariant differences in productivity across sectors, which might be correlated but not caused by foreign presence, they fail to establish causality and are likely to generate biased coefficients.
} 
productivity levels are in fact correlated with the pattern of foreign investment, biasing previous results. Once these productivity differences across industries are properly taken into consideration, they still find a positive relationship between increased foreign equity participation and plant's performance, suggesting that individual plants do benefit from foreign investment. However, the positive own-plant effect is only robust for small plants (defined as plants with less then 50 employees). More importantly, they find that, in contrast with what would be expected in the presence of positive externalities, productivity in domestically owned plants declines when foreign investment increases. Thus, the overall effect of foreign investment in the case of Venezuela is small.

The paper by Aitken and Harrison spawned a second-generation of empirical studies of FDI spillovers in which panel data are used to deal with the endogeneity problem that affected previous studies. In the particular case of developing countries, these studies find no indication of the existence of positive horizontal externalities. In fact, many studies find evidence of negative horizontal externalities. In a recent review of the micro evidence on externalities from foreign owned to domestically owned firms which pays particular attention to panel studies, Gorg and Greenaway (2002) conclude that the effects are mostly negative. ${ }^{9}$

One explanation for the lack of evidence for externalities is that multinationals have the incentive to minimize technology leakages to competitors while improving the productivity of suppliers by transferring knowledge to them. Thus, if FDI were to generate spillovers, they are more likely to be vertical rather than horizontal in nature. Most empirical studies of FDI spillovers have regressed local firm productivity on FDI activity within the same sector. Although such studies find no horizontal spillovers, the empirical work at the intra-industry level might not be suitable to capture wider spillover effects on the host economy such as those created between MNCs and their suppliers. For example, using industry level panel data for ten Colombian manufacturing sectors from 1974-1998, Kugler (2001) finds evidence of inter-industry linkages. However, only in

\footnotetext{
${ }^{9}$ Grog and Greenaway's (2002) survey of studies using panel data sets finds that only two studies for industrialized countries and none for developing countries report positive evidence for within-industry externalities; all other studies using panel data find either negative or no statistically significant effects.
} 
one sector does he find evidence of intra-industry spillovers. ${ }^{10}$ Kugler, however, does not explore the mechanisms that may be behind these inter-sector externalities.

In recent years a new group of papers (which we label third-generation papers) has explored the existence of positive externalities from FDI towards local firms in upstream industries (suppliers). Here the findings are more encouraging (see Table 1). Furthermore, these papers have addressed a series of methodological problems in the previous literature, such as the biases that result from the dependence of firm exit and usage of factor inputs on productivity levels. Three recent papers on FDI and vertical spillovers control for time-invariant differences in plant productivity through fixed effects estimation and for time-variant productivity shocks likely to affect plant productivity using the semi-parametric estimation proposed by Olley and Pakes (1996). ${ }^{11}$ Using panel data for Lithuania from 1996 through 2000, Javorcik (2003) examines whether the productivity of domestic firms is correlated with the presence of multinationals in downstream sectors (potential customers). Her empirical results are consistent with the existence of productivity externalities from FDI taking place through contacts between foreign affiliates and their local suppliers in upstream sectors but there is no indication of externalities occurring within the same industry. ${ }^{12}$

Similarly, using a panel dataset of Indonesian manufacturing establishments from 1988 through 1996, Blalock and Gertler (2003) find evidence of positive vertical externalities. They also find that downstream FDI increases output and firm value added while decreasing prices and market concentration. Finally, using plant-level data for manufacturing firms in Mexico from 1993 through 2000, López-Córdova (2003) finds

\footnotetext{
${ }^{10}$ Kugler (2001) uses cointegration techniques to determine whether or not a relationship exists between capital accumulation by foreign firms and domestic productivity in a sector. If there is such a relationship, this is taken as evidence for productivity spillovers.

${ }^{11}$ Olley and Pakes (1996) propose using investment as a proxy for idiosyncratic shocks, conditional on capital. Because capital responds to the shocks only in a lagged fashion through contemporaneous investment, the return to the other can be obtained by non-parametrically inverting investment and capital to proxy for the unobserved shock. See Pavnic (2001) for an application of this estimation algorithm to study the effects of liberalized trade on plant productivity in Chile.

${ }^{12}$ Javorcik (2003) uses Olley and Pakes (1996) to account for endogeneity of input demand and corrects standard errors to take into account the fact that the measures of potential spillover are industry specific while the observations in the data set are at the firm level - which could lead to serious downward bias in the estimated errors. In her panel evidence without Olley-Pakes correction, she finds evidence consistent with the existence of positive spillovers from FDI taking place through backward linkages but no indication of spillovers occurring through horizontal channels. When applying the Olley-Pakes correction, however, the coefficients on the backward variable are positive but not significant at the conventional levels.
} 
that foreign capital improves total factor productivity (TFP), with positive inter-industry externalities prevailing over a negative intra-industry effect.

Overall, however, the existing evidence needs to be taken with caution. Methodological issues remain regarding estimation techniques and measurement of variables, in particular productivity measures. As Tybout (2001) and Katayama, Lu and Tybout (2003) note, inputs and outputs are typically poorly measured and - most importantly - physical outputs are not really observed; what is usually measured are nominal variables deflated by a broad price index. ${ }^{13}$ This can lead to bias in the productivity measures. If, for example, firms that expand rapidly also tend to drive their output prices down relatively rapidly, as one would expect in differentiated product markets, then output growth is underestimated when input growth is rapid. In this case, markups, productivity measures and other derived calculations would be biased.

Summarizing, one conclusion that emerges from the empirical literature is that it is difficult to find robust evidence of positive externalities from multinationals to local firms in the same sector (horizontal externalities). In fact, many studies for developing countries that have paid particular attention to causality problems have actually found evidence of negative horizontal externalities arising from multinational activity while confirming the existence of positive externalities from multinationals to local firms in upstream industries (vertical externalities). Although, as explained above, methodological issues remain unsolved in the literature, our goal, with these caveats in mind, is to try to understand these findings and explore whether linkages can explain some of them.

\section{3 - Preliminary discussion: multinationals, knowledge spillovers, and backward linkages}

The empirical literature reviewed in the previous section does not address the mechanisms behind the horizontal and vertical FDI externalities. This may be appropriate as a first stage, but we believe it is now important to look into this matter both because it

\footnotetext{
${ }^{13}$ See Tybout (2001) for an overview of the evidence and methodological issues regarding firm-level studies of TFP and Katayama, Lu and Tybout (2003) for an alternative approach.
} 
could help us determine the robustness of the findings and because it is important if we want to device appropriate policy interventions to maximize FDI externalities.

There are different mechanisms through which FDI could generate positive production externalities. One such mechanism depends on the flow of workers out of MNCs. ${ }^{14}$ For example, it may be that MNCs devote more resources to labor training than domestic firms. Given that a large part of this labor training is not paid for by workers and constitutes knowledge that is not completely firm specific, this constitutes a positive externality which leads to higher wages for these workers and/or higher productivity for firms that hire these workers after they leave the MNCs. In general, these labor training externalities would show up as "horizontal" knowledge spillovers, in the sense that they would benefit other firms in the same sector as the MNCs. Something very similar happens if workers increased their knowledge not through formal labor training but through on the job training, learning by doing or learning by observing. The spillover can also take place through "spin-offs." These are the cases where workers leave the MNC to set up their own firms and benefit from the knowledge they gained while at the MNC.

As Fosfuri, Motta and Ronde (2001) note, there is evidence that MNEs undertake substantial efforts in the education of local workers (Lindsey, 1986; Ritchie, Zhuang and Whitworth, 2001) and that MNEs offer more training to technical workers and managers than do local firms (Chen, 1983; Gershenberg, 1987). ${ }^{15}$ Studying the case of Taiwan, Pack (1997) finds evidence that trained managers often leave MNCs to create their own firms and that labor mobility from MNCs to domestic firms is important. In some cases, MNCs also enter into training cooperation with local institutions in the host economy. For example, Intel in Costa Rica and Shell-BP in Nigeria have made contributions to local universities; in Singapore, the Economic Development Board has collaborated with MNCs to establish and improve training centers, (World Bank, 1995; Spar, 1998; Larraín, López, and Rodríguez-Clare, 2000).

\footnotetext{
${ }^{14}$ Fallick, Fleischman and Rebitzer (2003) investigate the role of knowledge spillovers due to easy mobility of skilled employees among firms in Silicon Valley.

${ }^{15}$ Fosfuri, Motta and Ronde (2001) formalize this view. In their model, a multinational firm can use a superior technology only after training a local worker. Technological spillovers from FDI arise when a domestic firms hires such worker. Pecuniary spillovers arise when the foreign affiliate pays higher wages to prevent the worker form leaving.
} 
Knowledge spillovers can also take place without formal flows of workers out of the MNCs. One would expect that knowledge about production process would diffuse from one firm to others simply because of the regular human interaction among people performing similar jobs for different companies. For example, a simple innovation introduced by one MNC in the maquila sector in Honduras was to provide a free breakfast to employees half an hour before the start of the morning shift. This not only provided incentives for workers to show up on time but also helped to improve their productivity. This simple idea rapidly diffused to other firms and soon became the norm in the maquila sector. More sophisticated or tacit knowledge can also diffuse in cases where there is close interaction between MNCs and local firms, as for instance in the case of MNCs and their suppliers. Branstetter (2000), for example, using firm level data on Japanese firms' FDI and innovation activity, finds evidence that FDI increases the flow of knowledge spillovers (measured by patent citations) both from and to Japanese multinationals undertaking direct investment in the U.S.

An entirely different mechanism for FDI externalities occurs through backward and forward linkages. It is important to distinguish linkages from spillovers, as they have often been confused in the literature. Following Hirschman (1958), we view linkages as pecuniary externalities. In contrast to knowledge spillovers, pecuniary externalities take place through market transactions. Consider, for example, the case of a firm that invents a new good. Under realistic assumptions, such a firm will not be able to capture the full consumer surplus generated by the introduction of the good. Thus, there will be a positive pecuniary externality from the firm to consumers when the good is introduced. The same phenomenon arises when, instead of inventing a new good, the firm is simply starting up its production in a developing country. Of course, under constant returns to scale, all goods generating positive consumer surplus would be produced and there would be no inefficiency. But consider the more realistic scenario in which there are fixed or start-up costs. In this case, new goods will be introduced until the marginal good just earns enough profits to generate the market return on the firm's fixed investment. The problem, however, is that this does not take into account the consumer surplus generated by each new good. Hence, there will be a market 
inefficiency associated with the pecuniary externality, resulting in suboptimal equilibrium variety.

Readers will notice that this discussion has implicitly assumed some kind of non-tradability. If goods were perfectly tradable (i.e., there were no transportation costs) then it wouldn't make sense to talk about a firm introducing a good to a developing country: all existing goods would be automatically available everywhere as long as there was a demand. But, of course, there is ample evidence that transportation costs are important, and - more generally - there is evidence of the existence of important benefits to having inputs produced locally.

Backward and forward linkages are associated with pecuniary externalities in the production of inputs. Inputs that would generate a positive social value are not introduced because suppliers do not take into account the full producer surplus, which in this case is the increased productivity derived by firms that could use those inputs instead of others that are less specialized and hence less appropriate to the specific needs of the firm. Under these circumstances (inputs produced with increasing returns, transportation costs, and benefits of specialization), backward linkages are said to arise when a firm increases the demand for inputs and this leads to the introduction of new input varieties. Thanks to the benefits of specialization, the introduction of these inputs generates an increase in productivity for downstream producers. Thus, backward linkages entail a positive horizontal productivity externality.

Forward linkages take place when the introduction of new inputs lowers the production cost of certain goods, making their production profitable for downstream producers. In Rodríguez-Clare (1996), for example, MNCs may create backward linkages and thereby lead to the production of a larger variety of intermediate goods; in turn, this allows the economy to gain a comparative advantage in the production of more sophisticated final goods. In the end, the economy ends up with higher productivity and higher wages thanks to the backward and forward linkages generated by MNCs.

According to this view of linkages, MNCs could even generate a negative backward-linkage effect, as shown in Rodríguez-Clare (1996). This could occur, for 
example, if MNCs behave as enclaves, by importing all their inputs and restricting their local activities to hiring labor. In this case, demand for inputs decreases as MNCs increase in importance relative to domestic firms and this leads to a reduction in input variety and specialization. This would show up as a negative horizontal externality. ${ }^{16}$

\section{4 - A simple model of backward linkages}

In this section we present a simple model adapted from Rodríguez-Clare (1996) to formalize the idea of backward linkages in an economy with several sectors. We then propose a way to measure a firm's linkage generating potential, discuss the conditions under which it would be valid, and discuss alternative measures.

\section{1 - The model}

Consider an economy (the host country) producing $\mathrm{J}$ manufacturing goods and an agricultural good. The agricultural good is produced one for one with labor, L, and is perfectly traded, with an international price equal to one. Thus, this good acts as the numeraire, and sets the wage equal to one. Imagine for simplicity that this is a small economy that takes final good prices as given, and let $p_{j}$ represent the price of manufacturing good $\mathrm{j}$. Both domestic firms and multinationals produce manufacturing good $\mathrm{j}$. Domestic firms produce good $\mathrm{j}$ with labor that is specific to sector $\mathrm{j}$ (and available in total quantity $\bar{L}_{j}$ in the economy) and a composite intermediate good, X, according to the following Cobb-Douglas production function:

$$
Q_{j}=A(j) L_{j}^{\beta(j)} X_{j}^{1-\beta(j)}
$$

where $0<\beta(j)<1$. In turn, $\mathrm{X}$ is assembled from a continuum of non-tradable differentiated intermediate goods according to the following Dixit-Stiglitz-Ethier specification:

\footnotetext{
${ }^{16}$ Note that in this argumentation it is key that MNCs displace national firms from the market: this can be due to labor market constraints (in the case of exports) or it could be that MNCs compete with domestic firms in the local market, as in Markusen and Venables (1999).
} 


$$
X=\left(\int_{0}^{n} x(i)^{\alpha} d i\right)^{1 / \alpha}
$$

where $0<\alpha<1 .{ }^{17} \mathrm{We}$ assume that there is a fixed requirement of one unit of $\mathrm{L}$ to produce a variety of intermediate goods and that production of each additional unit of such goods requires one additional unit of $\mathrm{L}$.

Multinationals produce good $\mathrm{j}$ with a production function that is the same as the one for domestic firms except for the parameter $\beta(j)$, which we denote by $\tilde{\beta}(j)$ in the case of multinationals. In general, we will think of $\tilde{\beta}(j)<\beta(j)$, to capture the idea that multinationals have a more "complex" or "roundabout" production process, which depends more on intermediate goods and less on labor. ${ }^{18}$ An additional difference between multinationals and domestic firms is that the former have access to intermediate goods from the country where they have their headquarters. Thus, whereas domestic firms source all their intermediate goods domestically, multinationals buy only part of them domestically and import the rest from their home country.

As is standard in the literature, we assume that there is monopolistic competition in the market for intermediate goods, with a different firm selling each variety. The equilibrium variety $\mathrm{n}$ is determined by the zero-profit condition for monopolists selling intermediate-good varieties. Each firm will charge a price equal to $1 / \alpha$ (recall that the wage is equal to one) and make profits equal to $x / \theta-1$, where $\theta \equiv \alpha /(1-\alpha){ }^{19}$ Thus, the zero profit condition implies $x(j)=\theta$.

Since labor cannot move across manufacturing sectors, then we must allow the wage in sector $\mathrm{j}, w_{j}$, to differ from the wage in other manufacturing sectors. Wages will be determined by the zero profit condition for final good producers in each

\footnotetext{
${ }^{17}$ Alternatively, we could assume that there are some inputs that are tradable and others that are nontradable, as long as there are no differences across domestic and multinational firms as to which of these inputs they use. We believe that the same results would arise if instead of the extreme assumption of nontradability we assumed that inputs had significant transportation costs, something for which there is ample evidence (see the discussion in section 4.1).

${ }^{18}$ This would also arise if multinationals use technologies that are more capital intensive relative to domestic firms and if capital is complementary with intermediate goods. We could easily introduce capital into the model without changing any of the substantive results as long as multinationals do not compete with domestic firms for capital. We believe that this is a reasonable assumption, as the main area of competition between multinationals and domestic firms is for labor (perhaps only skilled labor, see below).

${ }^{19}$ Given that the firm sells $\mathrm{x}$ units at price $1 / \alpha$ and unitary cost, then variable profits are $(1 / \alpha-1) x=x / \theta$. Total profits are variable profits minus the fixed cost, which is simply one.
} 
manufacturing sector. More importantly, it can be shown that the quantity of each variety of $\mathrm{x}$ that final good producers purchase per unit of labor hired is given by $\alpha v(j) w_{j} / n$, where $v(j) \equiv(1-\beta(j)) / \beta(j)$. To proceed, imagine first that there were no multinationals. Then the total demand for each variety of x would be $\sum_{j} \alpha v(j) w_{j} \bar{L}_{j} / n$. Without loss of generality, we choose the values for $A(j)$ in such a way that the minimum unit cost of manufacturing good $\mathrm{j}$ is $\alpha^{\beta(j)-1} n^{(\beta(j)-1) / \theta} w_{j}{ }^{\beta(j)} \cdot{ }^{20}$ In turn, this implies that the equilibrium wages are given by $w_{j}(n)=p_{j}{ }^{1 / \beta(j)} \alpha^{v(j)} n^{\nu(j) / \theta}$. Thus, the equilibrium condition that determines $\mathrm{n}$ is:

$$
\sum_{j} \alpha v(j) w_{j}(n) \bar{L}_{j} / n=\theta
$$

We make the assumption that $v(j)<\theta$ for all $\mathrm{j}$, which implies that the share of intermediate goods relative to labor in the production of final good $\mathrm{j}$ is lower than the (absolute value of) the elasticity of substitution across varieties of intermediate goods. This condition is sufficient to guarantee that the LHS of (3) is decreasing in $n$ and hence that there is a unique equilibrium value of $n^{21}$

Our interest now is in understanding the effect of multinationals on the equilibrium n. Imagine that multinationals hire $L_{m j}$ units of labor in manufacturing sector j. As in the case of domestic firms, it is useful to derive the multinationals' demand for each variety of intermediate goods in the host country per unit of labor hired there. This is given by $\gamma(j) \sigma_{j}(n)^{1 / \tilde{\beta}(j)} \alpha \tilde{v}(j) w_{j}(n) / n$, where $\tilde{v}(j) \equiv(1-\tilde{\beta}(j)) / \tilde{\beta}(j)$. The term $\gamma(j)$, which will generally be strictly lower than one, is the share of inputs sourced domestically by multinationals. As shown in Rodríguez-Clare (1996), $\gamma(j)$ is higher when the variety of intermediate goods available in the home country is lower and when the transportation cost of intermediate goods is higher, perhaps because the home country is far away from the host country. The term $\sigma_{j}(n)$ is the ratio of the price of good $\mathrm{j}$ and

\footnotetext{
${ }^{20}$ Specifically, we assume that $A(j)=\beta(j)^{-1} v(j)^{\beta(j)-1}$.

${ }^{21}$ If, on the other hand, the share of intermediate goods in manufacturing is high and/or the elasticity of substitution across intermediate goods is low (implying a high degree of love of variety), the wage will be increasing very rapidly in $\mathrm{n}$. This could make the LHS of (3) increasing in n, in which case there would not be an equilibrium with unitary wage, as we have been assuming.
} 
the minimum unit cost for multinationals. Since multinationals have access to intermediate goods from abroad and since $\tilde{\beta}(j) \neq \beta(j)$, their minimum unit cost will be lower than for domestic firms, and hence this ratio will be higher than one. This term is increasing in $\mathrm{n}$ because as $\mathrm{n}$ increases, the wage $w_{j}$ increases, and given that $\tilde{\beta}(j)<\beta(j)$, this increases the unit cost of domestic firms more than for multinationals.

We can see that there are two sources of differences in the purchases of intermediate goods per unit of labor hired between multinationals and domestic firms. The first relates to the share parameter, defined by the share of inputs bought domestically. This is equal to one for domestic firms and $\gamma(j)<1$ for multinationals. The second is the intensity parameter, defined as the quantity of each variety of the intermediate good bought domestically per unit of labor hired. This is captured by $\alpha v(j) w_{j}(n) / n$ and $\sigma_{j}(n)^{1 / \tilde{\beta}(j)} \alpha \tilde{v}(j) w_{j}(n) / n$ for domestic firms and multinationals, respectively. With $\tilde{\beta}(j)<\beta(j)$ then we have that $\tilde{v}(j)>v(j)$. Together with the fact that $\sigma_{j}(n)>1$, this results in a higher intensity parameter for multinationals than for domestic firms.

We assume that entry by multinationals is exogenous. Thus, we simply take a distribution of $L_{m j}$ across manufacturing sectors as given. Then, the equilibrium is determined by:

$$
\sum_{j} \alpha\left(w_{j}(n) / n\right)\left(v(j)\left(\bar{L}_{j}-L_{j m}\right)+\gamma(j) \sigma_{j}(n)^{1 / \tilde{\beta}(j)} \tilde{v}(j) L_{j m}\right)=\theta
$$

It is important, again, to ensure that the LHS of (4) is decreasing in n, so that the equilibrium level $\mathrm{n}$ determined implicitly by this equation is unique. As we show in Appendix A, a sufficient condition for this is that $\left(\frac{1-\tilde{\beta}(j)}{\tilde{\beta}(j)}\right)<\theta$ for all $\mathrm{j}$. As we had before for domestic firms, this implies that the share of intermediate goods in multinationals production of manufactures is not too high relative to the elasticity of substitution across inputs.

The impact of changes in $L_{j m}$ depends on the relationship between $v(j)$ and $\gamma(j) \sigma_{j}(n)^{1 / \tilde{\beta}(j)} \tilde{v}(j)$. In particular, it is easy to see that the equilibrium level of $\mathrm{n}$ is 
increasing in $L_{j m}$ if and only if $\gamma(j) \sigma_{j}(n)^{1 / \tilde{\beta}(j)} \tilde{v}(j)>v(j)$. We refer to this case as one where there is a positive linkage effect of multinationals. On the other hand, if $\gamma(j) \sigma_{j}(n)^{1 / \tilde{\beta}(j)} \tilde{v}(j)<v(j)$, then multinationals have a negative linkage effect and equilibrium $\mathrm{n}$ is decreasing in $L_{j m}$. The intuition for this result is that if $\gamma(j) \sigma_{j}(n)^{1 / \tilde{\beta}(j)} \tilde{v}(j)<v(j)$, then a stronger presence of multinationals reduces the demand for domestic intermediate goods because multinationals' demand for these intermediate goods per unit of labor is lower than for the domestic firms they displace from the labor market in.

The importance of the linkage effect, of course, arises from the fact that there is love of variety for inputs. That is, productivity of final good producers increases with an increase in the variety of domestic intermediate goods produced (this is why $w_{j}(n)$ is increasing in $n$ ). This can be seen as capturing the benefits of specialization or the productivity gains from the division of labor. The positive association between intermediate goods variety (n) and productivity of final good producers implies that a positive (negative) linkage effect has a positive (negative) effect on productivity among domestic firms. $^{22}$

To conclude this subsection, it is worth stressing two points that emerge from our analysis. The first point is that multinationals' share coefficient measured by most studies of linkages does not capture the whole story. The share coefficient most likely will be lower for multinationals than for domestic firms, but the linkage coefficient is the product of two terms: the share coefficient and the intensity coefficient. Given that, as we have shown, the intensity coefficient most likely will be higher for multinationals than for domestic firms, conclusions based on comparisons of only the share coefficient are likely to be wrong. The second point is that a positive backward linkage effect by multinationals leads to a positive effect on TFP for firms in the same industry, rather than for firms in upstream industries. In other words, a positive backward linkage effect leads

\footnotetext{
${ }^{22}$ Notice that in the model we have presented, a positive linkage effect of multinationals in manufacturing sector $\mathrm{j}$ implies an increase in variety that benefits all manufacturing sectors. This is because we have assumed that intermediate goods are not sector specific. Alternatively, we could assume that all intermediate goods are sector specific, in which case a positive linkage effect in sector $\mathrm{j}$ would only benefit domestic firms in that same sector. The theoretical and empirical analysis are not affected by this change in assumptions, so it is just a matter of interpretation.
} 
to a positive horizontal externality rather than a positive vertical externality, as often has been assumed.

\section{2 - Measuring the linkage coefficient}

Under the assumptions of the model presented in this section, the appropriate measure of the linkage coefficient is the value of inputs bought domestically per unit of labor hired. Let us consider the different key assumptions for this result and how the violation of these assumptions would affect the validity of our measure for the linkage coefficient.

First, a key assumption is that all the intermediate goods used by domestic firms are non-tradable. This is clearly a very extreme assumption and could significantly affect the results of the model. For instance, consider a model with two kinds of inputs: nontradable and tradable with no transportation costs. Clearly, only demand for non-tradable inputs generates meaningful linkages. Imagine that we found that the linkage coefficient defined above is higher for multinationals than for domestic firms. This would lead to the conclusion that multinationals have a positive linkage effect, but this would be wrong if multinationals buy mostly tradable inputs, whereas domestic firms buy mostly nontradable inputs. Ideally, we would take into account only the purchases of non-tradable inputs, but this is clearly impossible in most cases due to data constraints. In Section 5, we explore this topic further.

Second, another key assumption in our model is that the degree of increasing returns is the same for all intermediate goods. But imagine a situation where intermediate goods exhibit either increasing returns, as in the model above, or constant returns to scale. Clearly, only demand for intermediate goods of the first kind entails linkages. Thus, one could imagine a situation where multinationals have a higher linkage coefficient and yet, if domestic firms use mostly inputs with increasing returns and multinationals use mostly inputs with constant returns, the conclusion of a positive linkage effect by multinationals would be incorrect. Given data constraints, again, there is little we can do at this stage regarding this issue.

Third, a further concern with the measurement we propose is related to our assumption of a common elasticity of substitution among all intermediate goods. This is 
relevant because demand for inputs with a low elasticity of substitution generate linkages with a stronger effect on productivity than is the case with inputs that have good substitutes. Thus, in the same spirit as the arguments above, it could be that multinationals have a higher linkage coefficient than domestic firms and yet their linkage effect is negative because they demand mostly inputs with good substitutes, whereas domestic firms demand inputs with bad substitutes.

A final concern we want to mention has to do with the model's assumptions regarding labor. The simplifying assumption we made is that multinationals and domestic firms employ the same kind of workers. But consider the more realistic scenario where multinationals hire more skilled workers than domestic firms. We could modify the model to capture this possibility by assuming that production of manufacturing goods is carried out with both skilled labor - which is sector specific - and unskilled labor which is mobile across sectors and in particular equal to labor used in agriculture. In this case, it can easily be shown that the relevant linkage coefficient is the ratio of inputs bought domestically to the number of skilled workers employed. Again, one can imagine a situation where the linkage coefficient defined above is higher for multinationals than for domestic firms but where this modified linkage coefficient (dividing by the number of skilled workers rather than the total number of workers) is lower for multinationals than domestic firms. ${ }^{23}$ Fortunately, data for some of our countries allows us to explore the importance of this issue.

\section{3 - Evidence in favor of the model}

In the next section we will explore the quantitative implications of the model. This empirical exercise is meaningful only to the extent that the model captures the essence of the way in which multinationals affect host countries through linkages. What evidence do we have to lead us to believe that this is the case? There are two ways to approach this question: first, by exploring the reasonableness of the model's critical assumptions, and second, by reviewing the available evidence regarding the model's implications.

\footnotetext{
${ }^{23}$ Hanson (2001) makes a similar point by noting that positive externalities by multinationals are less likely when there is stronger competition for scarce skilled labor between multinationals and domestic firms.
} 
As to the first approach, recall that the three key assumptions of the model are that inputs are non-tradable and produced with increasing returns, and that there are benefits to specialization. Of course, non-tradability of inputs is only an extreme way to capture transportation costs in the model. Evidence of the importance of transportation costs for inputs can be found in Overman, Redding and Venables (2001). Four additional references may be useful: first, Hummels (1999, 2001) provides evidence of costs of international trade (which include tariffs and non-tariff barriers, shipping costs, costs of time delays, and other costs associated with marketing and distribution) for a large class of goods and inputs. Second, Steinberg (2002) shows that the production of most inputs in Singapore - a small and very open economy where one would think that everything is tradable - behaves as if inputs are non-tradable. Third, Klenow and Rodríguez-Clare (1997) and Hummels and Klenow (2002) show that variety of imports increases with country size, a result consistent with the existence of fixed costs of importing. Finally, a particular class of inputs that fit the model well is producer services, as discussed in Rodríguez-Clare (1993). Alternatively, one may think of the assumption of nontradability of inputs as capturing the benefits for producers to having local as opposed to foreign suppliers. This comes out clearly in interviews to multinationals as well as in case-study analysis, like those presented in Porter (1990).

The other two key assumptions of the model (increasing returns and benefits to specialization) are now standard in several fields of economics, such as international trade (Ethier, 1982; Helpman and Krugman, 1985), growth (Romer, 1990; Grossman and Helpman, 1992), development (Rodrik, 1995; Rodríguez-Clare, 1996), and economic geography (Fujita, Krugman and Venables, 1999). Moreover, there is good evidence on the importance of increasing returns in the production of producer services (RodríguezClare, 1993) as well as plant-level increasing returns in manufacturing (Tybout and Westbrook, 1995). Finally, there is recent evidence consistent with the implications of our three key assumptions working together, namely agglomeration economies (Ellison and Glaeser, 1997, 1999; Hanson, 2000) and sector wide increasing returns in international trade (Antweiler and Trefler, 2000).

Besides checking for evidence in support for the key assumptions in our model, an alternative approach involves testing the model directly. Most of what has been done so 
far in this regard entails case studies, with almost no rigorous empirical analysis. However, this literature, and particularly when analyzing East-Asian countries' cases, does provide evidence in support of the view that multinationals have been involved in positive linkage relations with domestic firm (Lall, 1980; Pack 1997; UNCTAD, 2001).

But, as mentioned, expect for few papers, there has not been a strong connection between theoretical and empirical work in this literature. The only empirical analysis that we are aware of is the one by Gorg and Strobl (2000). Following Markusen and Venables (1999), Gorg and Strobl (2000) estimate the factors that lead to entry of domestic firms in the manufacturing sector in the Irish economy. Their findings suggest there is a positive effect of MNC in domestic firm entry. Their work, however, defines the linkage-effect as the share of inputs sourced domestically, which as explained in Section 4, might be a misleading indicator of the true linkage potential of a firm.

\section{5 - Measuring linkage coefficients for MNCs and local firms in Latin America}

In this section we use our proposed measure of the linkage coefficient to explore the model's implied relationship between linkages generated by foreign and local firms in the several countries for which we obtained the appropriate data. Using this definition, we then compare our results with the main findings in the literature. It is important here to warn the reader again that the empirical exercise in this section does not involve a test of the model presented in the previous section. Instead, what we do is to explore its quantitative implications. We believe that actual testing of the model remains an important issue for future research.

\section{1 - Data}

The empirical analysis was performed using manufacturing firm data from Chile, Mexico, Venezuela and Brazil distinguished by sector and ownership. In all cases, a firmplant was considered foreign if foreigners owned more than $50 \%$ of equity.

For Brazil, the sample covers 1997 through 2000. The analysis is based on a dataset of firms taken for the Annual Industrial Survey (Pesquisa Industrial Annual, PIA), conducted by IBGE, Brazil's statistical office. The unbalanced panel has 38926 
observations, with 3118 foreign ones. The number of observations ranges from 10767 in 1997 to 8528 in 2000. For Chile, the sample covers firms in the manufacturing sector for the years 1987 through 1999 and was taken from the Annual Industrial Survey (Industrial Annual). Our sample includes 65809 observations, with 6223 foreign ones. The number of observations ranges from 5466 in 1996 to 4394 in 1999. Data for Mexico were taken from the Annual Industrial Survey (EIA, Encuestra Industrial Annual). Our sample covers the years 1993 through 2000 and includes 47914 observations, with 4071 foreign ones. The number of observations per year ranges from 6616 in 1993 to 5330 in 2000. Data for Venezuela are from the annual industrial survey of plants (Encuesta Industrial). The data covered the years 1995 through 2000. Our sample includes 13765 observations, and 1508 observations were classified as foreign. The number of observations covered ranges from 1785 in 1998 to 3572 in 1996.

\section{2 - Basic results for the linkage coefficient}

We calculated the linkage coefficient as the value of domestic inputs to total workers per year for each firm. Table 2a presents the main descriptive statistics for the linkage coefficient for the countries and years in our sample. As seen in Table 2a, there is wide variation in the linkage coefficient across countries and years and different patterns emerge. For Mexico, the linkage coefficient for foreign firms is lower than for local firms. In contrast, the linkage coefficient for Brazil, Venezuela and Chile is higher for foreign firms than for local ones.

In order to compare our linkage coefficient to those used in the literature, we also calculated the share of inputs sourced domestically per year by each firm. Table $2 b$ shows comparable statistics for this measure. In all cases, we observe a higher share of inputs sourced domestically by local firms versus foreign ones. For Mexico and Brazil, the share of domestic inputs sourced domestically is fairly constant throughout the period while for Chile it tends to decline and to increase in the case of Venezuela.

Finally, Table 2c reports the intensity coefficient, calculated as total inputs bought by the firm to total employees per firm (i.e. intensity coefficient $=$ linkage coefficient $\times$ share). There is also wide variation of this indicator throughout the sample. Overall, 
however, the intensity coefficient for foreign firms tends to be higher than for local firms for all countries in our sample.

\section{3 - Regression analysis}

We use the ratio of inputs bought domestically to workers as our linkage coefficient and explore the validity of the claims that have been made in the literature regarding linkages across different types of firms such as how the linkage coefficient compares between local and foreign firms. We estimate the following relation:

$$
\text { Linkage Coefficient }_{i j t}=\beta_{0}+\beta_{1} \text { Foreign }_{i j t}+\mu_{j}+\mu_{t}+\varepsilon_{i j t}
$$

where Linkage Coefficient $i j t$ refers to domestic inputs to total workers for firm $i$ in sector $j$ at time $t$; Foreign $n_{i j t}$ is a dummy variable taking the value of one if firm $i$ in sector $j$ at time $t$ is owned by foreigners ( $50 \%$ or more foreign equity); $\mu_{j}$ and $\mu_{t}$ are meant to capture sector and time specific effects, and $\varepsilon_{i j t}$ is an iid error term. ${ }^{24}$

Table 3 presents the result of estimating equation (5) excluding the sectordummies. We find that multinational's linkage coefficient is significantly higher in Brazil, Chile and Venezuela. For Mexico, although our estimations imply a lower linkage coefficient for foreign firms, the coefficient is not significant at conventional levels. These results remain robust once we control for different sectors, as seen in Table $4 \mathrm{a}^{25}$ Once we control for sector differences, we find higher and significant linkage coefficients in Brazil, Chile and Venezuela. ${ }^{26}$ Interestingly, the coefficient for Mexico in the regression that controls for time and industry effects is now positive, although not significant. The estimated effects are also economically significant. An increase in the

\footnotetext{
${ }^{24}$ We used 9 sectors according to ISIC2 classification for Mexico, Chile and Venezuela. For Brazil, we have ISIC3 code- 15 sectors.

${ }^{25}$ Results are also robust to excluding outliers; similar results are obtained using log of the linkage coefficient..

${ }^{26} \mathrm{We}$ further explored for differences in terms of linkage potential for foreign firms at the sector level. We estimated the following relation: Linkage Coefficient $i j t=\beta_{0}+\beta_{1}$ Foreign $_{i j t}+\beta_{l}$ Foreign $_{i j t i} \times \mu_{j}+\mu_{j}+\mu_{t}+$ $\varepsilon_{i j t,}$ where the term Foreign $n_{i j t} \times \mu_{j}$ is meant to capture differences for foreign firms at the sector level. Although, we found foreign firms to have significantly different linkage potential across some sectors these
} 
presence of multinational firms in sector $i$ (as measured by the share of employment in multinational firms) from $10 \%$ to $11 \%$, implies an average increase in wages ranging from close to $0.2 \%$ in Venezuela to up to $0.6 \%$ in Chile. ${ }^{27}$

We compare our results to those obtained in the literature by using the percentage of inputs sourced locally, which has been used as an indicator of linkage effect in the literature. $^{28}$ In particular, we estimated an equation similar to (5) but with Share Coefficient ${ }_{i j t}$ as the dependent variable, where ShareCoefficient $t_{i j t}$ is the ratio of domestic inputs to total inputs for firm $i$ in sector $j$ at time $t$. Since the dependent variable can take values between 0 and 1 , we estimated this equation using a Tobit regression. ${ }^{29}$

As seen in Table 4b, we find the share of inputs sourced domestically to be lower for foreign firms in all countries. This is consistent with most of the empirical literature on linkages, where the usual approach has been to consider the share of inputs bought domestically. This generally leads to the finding that the share of local to total inputs is lower for MNCs, such as the findings of Forsyth (1972) for Scotland and Cohen (1973) and Biersteker (1978) in Nigeria. The case of Ireland has received particular attention in the literature. McAleese and McDonald (1978) and O'Loughlin and O'Farrell (1980) find that foreign subsidiaries in Ireland buy fewer local inputs than national firms. ${ }^{30}$ Barry and Bandley (1997) also find that foreign firms are more likely to import their inputs than local firms. More recently, Gorg and Ruane (2000) study the effect of foreign firms in the electronic sector in Ireland between 1982 and 1995. Defining backward linkages as the share of domestic inputs to total inputs, they find that foreign firms have lower linkages than local firms, although multinationals' linkages with the local economy tend to become stronger with time.

Our results suggest that some of the common notions in the literature about MNCs' linkage effects may be due to using linkage measures that are not properly

differences seemed to be country-specific. The model developed in Section 4 of the paper is silent, however, on the implications of these results.

${ }^{27}$ Appendix B explains in detail the derivation of this calculation and the assumptions behind it.

${ }^{28}$ See McAleese and McDonald (1978) and O'Loughlin and O'Farrell (1980), Gorg and Strobl (2002).

${ }^{29}$ See Gorg and Ruane (2000) for a similar treatment when analyzing the Irish case.

${ }^{30}$ In their work, McAleese and McDonald (1978) define backward linkages as the ratio of current expenditure in Ireland relative to total current expenditure by firms while O'Loughlin and O'Farrell (1980) define it as the percentage of raw materials and components sourced locally. 
derived from theory. As discussed before, using our proposed indicator, we find evidence that foreign firms have significantly higher linkage coefficient than local firms in Venezuela, Chile and Brazil. ${ }^{31}$ We further explored why our results differ from those of the current empirical literature by measuring the intensity coefficient, a concept introduced in the previous section and calculated as the ratio of total inputs used to the number of employees hired (note that linkage coefficient $=$ source coefficient $\mathrm{x}$ intensity coefficient). We then estimated a similar equation as (5) but with Intensity Coefficient $t_{i j t}$ as the dependent variable. The main results are reported in Table 4c. For all countries, we found significantly higher intensity coefficients for foreign firms. These results suggest that although domestic firms do source a larger percentage of their inputs domestically, they also buy fewer inputs in relation to the number of workers they hire. As a result, domestic firms do not necessarily generate stronger linkages than foreign firms.

It is interesting here to comment on the result that Mexico is the only country in which the linkage coefficient of MNCs is not significantly higher than for domestic firms. One possible explanation for this finding is that most of Mexico's MNCs have their headquarters in the United States, making it attractive for them to import most of their inputs from there (Rodríguez-Clare, 1996). Thus, one would expect the MNCs in Mexico to have a much lower share coefficient than domestic firms, and indeed this is what we find. As can be seen in Table 2b, the average share coefficient for MNCs and domestic firms in Mexico is $54 \%$ and $84 \%$, respectively, whereas the corresponding numbers are $68 \%$ and $93 \%, 79 \%$ and $86 \%$, and $87 \%$ and $92 \%$ for Brazil, Venezuela and Chile, respectively. We get the same results when controlling for sectors, as shown in Table 4b.

\footnotetext{
${ }^{31}$ As suggested by one of the referees, we explored whether exporting firms have a higher linkage coefficient than those firms whose production is aimed at the domestic market. In a regression, Linkage Coefficient $t_{i j t}=\beta_{0}+\beta_{1} D_{-} \operatorname{Exp}_{i j t}+\mu_{j}+\mu_{t}+\varepsilon_{i j t}$. where $D_{-} \operatorname{Exp}_{i t j t}$ is a dummy variable taking the value of one if firm $i$ in sector $j$ at time $t$ is exporting; we found that indeed this is the case. In our sample, the number of observations geared to the external market ranges from $30 \%$ in Mexico to $15 \%$ in Chile. The results are significant for Chile and Venezuela. Moreover, the share of inputs sourced domestically for exporting firms is lower than that for firms oriented to the domestic market. This last result is significant for all countries. Our evidence suggests that these results are also driven by the higher intensity coefficients of exporting firms relative to those geared to the domestic market. In contrast with the results on MNCs that we report in the text, it is not entirely clear how to interpret these results regarding exporting firms. This remains an issue for future research.
} 


\section{New Foreign Firms and Time Effects}

Firms might need time to get to know the domestic market and establish relationships with the local economy. This means that the linkage effect may be different for well-established firms versus those just entering the market. To explore this, we regressed the linkage coefficient on the foreign dummy, time and sector dummies, and an interaction term meant to capture the effect of new foreign firms. Formally, we estimate the following relation:

(6) Linkage Coefficient $t_{i j t}=\beta_{0}+\beta_{1}$ Foreign $_{i j t}+\beta_{2}$ Foreign $_{i j t} \times$ NewFirms $_{i j t}+\mu_{j}+\mu_{t}+\varepsilon_{i j t}$

where New Firms $s_{i j t}$ is a dummy variable that takes the value of one for firms with less than three years of age. Since the hypothesis under study is relevant only on foreign firms, we interact this variable with the foreign dummy. As shown in Table 5a, new foreign firms tend to have a lower linkage coefficient. However, this result is significant only for Venezuela. ${ }^{32}$ Because our data sets for Brazil and Chile did not include age information, we were not able to perform this exercise for those countries.

It is reasonable to think that this result arises because the share coefficient for new MNCs is lower than for older MNCs, as it takes time for new foreign firms to find reliable local suppliers. Support for this hypothesis is not robust. As seen in Table 5b, running a regression similar to (6) but with the share coefficient as the dependent variable yields a negative and significant coefficient (for the interacted variable) in Mexico, but the results for Venezuela were not significant.

\footnotetext{
${ }^{32}$ In this case, the coefficient on Foreign $n_{i j t} \times$ New firms $s_{i j t}$ indicates that the linkage coefficient for these firms is lower than that of well-established foreign firms. In order to obtain the total estimated linkage coefficient for new foreign firms, one should add to this coefficient the estimated coefficient for foreign firms, the corresponding sector and year dummies and the constant. For both Mexico and Venezuela, the results imply a positive total linkage coefficient for new foreign firms. For Mexico the estimated coefficient for the constant was 81.39 (1.69) and all year dummies had significant positive values higher than 35.07. For Venezuela, the estimated coefficient for the constant was 1174.3 (3.57) and all year dummies had significant positive values higher than 3987.4. Note however, that we may be using a linear approximation to estimate a non-linear relation of age on the linkage coefficient.
} 
In order to explore this further, we analyzed how the share of inputs bought domestically by foreign firms was likely to evolve throughout time. For that, we estimate the following relation for foreign firms:

$$
\text { Share Coefficient } t_{i j t}=\delta_{0}+\delta_{1} t+\mu_{i j}+\varepsilon_{i j t}
$$

where $t$ stands for time (year) and $\mu_{i j}$ corresponds to a firm-specific effect. We conjecture that once we control for firm characteristics, we should observe foreign firms buying an increasingly higher percentage of inputs domestically. That is, we should observe a positive coefficient on the time trend variable.

In effect, we find a positive coefficient for all countries in our sample. However, only in the case of Mexico do we find strong evidence that as time progresses, foreign firms increase the share of inputs sourced domestically. For the other countries, the relation, although positive, is not significant. Likewise, the work by Gorg and Ruane (2000) in Ireland finds a positive and statistically significant relationship between the extent of linkages and a proxy for firm maturity, as indicated by the date at which the firm entered the survey. Their results, consistent with our findings, suggest that as firms get accustomed to local markets, they source more inputs locally.

\section{Robustness: Linkages measure}

As explained in Section 4, one potential problem with the measurement of the linkage coefficient we have used above has to do with differences in the type of workers hired by multinationals and domestic firms. Indeed, the empirical literature finds robust evidence that multinationals pay higher wages per employee than domestic firms, and we strongly confirm this in our data: in all cases, running a regression of the wage (total wages paid over total employees) on a foreign dummy results in a positive and significant coefficient, as seen in Table $7 .{ }^{33}$ Of course, one likely explanation for such higher wages

\footnotetext{
${ }^{33}$ We estimate an equation similar to (5) but with Average Wage $_{i j t}$ as the dependent variable, where Average Wage $_{i j t}$ corresponds to total wages per employee in firm $i$ in sector $j$ at time $\mathrm{t}$ and the rest is as in the previous equations.
} 
has to do with the payment of efficiency wages by multinationals. But it is also likely that part of the reason is that multinationals hire more skilled workers.

Unfortunately, we only have data on the type of workers hired for Venezuela and Mexico. For these countries, we confirm the above conjecture: the share of workers that are skilled is higher for multinationals than for domestic firms. ${ }^{34}$ Could it be that the results presented above change once we take this into account? Following the discussion in the previous section, we calculated the linkage coefficient as the ratio of domestic inputs to qualified employees and revisited our estimations with this new measure. The main results are reported in table 8a. After controlling for time and sector dummies, we still cannot reject the claim that foreign and local firms have similar effects in terms of linkages. How do the results compare to those previously obtained using total inputs to total workers as defined in equation (1)? In the case of Mexico, for both indicators we find that foreign firms have a higher linkage potential than domestic firms. In neither case, however, are the results significant at conventional significance levels. For Venezuela, however, our results remain positive. But in contrast to the results previously obtained, the results are not significant at $10 \%$.

Table $8 \mathrm{~b}$ presents the results of running our alternative intensity measure defined as the ratio of domestic inputs to qualified employees on the foreign dummy and time and sector dummies. For both Mexico and Venezuela, the intensity coefficient remains significantly higher for foreign firms, as seen in Table $8 \mathrm{~b}$. In this case, in relation to previous findings reported in Table $4 \mathrm{~b}$, the results remain robust only for Mexico.

\section{Summary}

Consistent with previous findings in the literature, we find that foreign firms in Mexico, Chile, Venezuela and Brazil source a lower percentage of their inputs domestically when compared to local firms. However, when we use our proposed measure of a firm's (backward) linkage potential, we do not find evidence that MNCs have a lower linkage potential. In fact, when we use domestic inputs to total workers as

\footnotetext{
${ }^{34}$ Formally, we estimated an equation similar to (5) but with Share Skilled ${ }_{i j t}$, where Share Skilled $d_{i j t}$ corresponds to the ratio of non production workers to total workers in firm $i$ in sector $j$ at time $\mathrm{t}$ and the rest is as in the previous equations.
} 
the linkage coefficient, we find that multinational's linkage potential in Brazil, Chile and Venezuela is higher than for domestic firms. For Mexico, the coefficient, although positive, is not significant. Using domestic inputs to skilled-workers, however, allows us to conclude that foreign and local firms have similar linkage potential in Mexico and Venezuela.

An important caveat of our analysis is that for linkages to be meaningful it must be that inputs are non-tradable (or, more generally, have high costs associated with importing them, relative to domestic procurement) and produced with increasing returns to scale. Unfortunately data limitations do not allow us to control for non-tradability and the degree of increasing returns. The approach we follow so far can be interpreted as establishing upper bounds on the linkages that can be generated by different firms. A more rigorous analysis of this question requires considering only the purchases of nontradable inputs and produced with increasing returns to scale.

\section{4- The Case of Costa Rica}

Although Costa Rica does not have good plant-level data, the country collects detailed information on all firms under the Export Processing Zone (EPZ) regime. ${ }^{35}$ One advantage of this data set is that it contains detailed information on the inputs used by each firm. This allows us to explore an issue mentioned above, namely the possibility that the tradability of inputs may vary across foreign and domestic firms. We briefly report on the findings although we stress that any generalization should keep in mind the limited nature of our data.

One robust finding, even in this small sample, is that domestic firms source a higher percentage of inputs locally than foreign firms. Moreover, consistent with previous results, we do not find evidence that foreign firms have a different linkage potential than domestic firms, although this could be due to the small size of our sample.

\footnotetext{
${ }^{35}$ In particular, we have firm data by nationality and sector from the EPZ regime for 1995 and 2000 . We have an unbalanced panel with only 118 observations; 57 for 1995 and 61 for $2000 ; 70 \%$ of the firms are foreign ones. In this case, firms where either foreign or local.
} 
As mentioned, the data set does allow us to investigate the tradability of the inputs used by different firms. For each input, we construct a tradability index as world trade (exports plus imports) to world production:

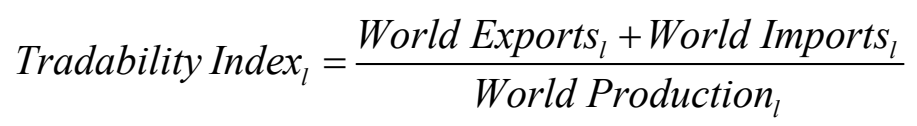

We then calculated the average tradability of inputs bought domestically by each firm according to:

$$
\text { Input Tradability }_{i}=\sum_{l}\left(\frac{x(l, i)}{\sum_{l} x(l, i)}\right) \text { Tradability Index } x_{l}
$$

where $x(l, i)$ denotes spending by firm $i$ in input $l$.

We used data from UNIDO's Industrial Demand-Supply Balance Database (2002) to construct the tradability index and then ran a regression of Input Tradability $i$ on a foreign dummy with year and sector dummies and verified that multinationals are using domestic inputs that are more tradable. ${ }^{36}$ This suggests caution in interpreting the above results since - as mentioned in the previous section - higher tradability implies less room for meaningful linkages.

Of course, our results are derived form a very particular case. Any conclusion or generalization must keep in mind that we have a small sample of firms located in the EPZ regime, which might not necessarily reflect the characteristics of firms in the country. However, this case does suggest further research should explore the role of the tradability of inputs, as they might be an important determinant when analyzing the linkage potential of foreign firms. Unfortunately, the small sample size of our data prevents us from pursuing this further.

\footnotetext{
${ }^{36}$ The sectors into which we classified firms are maquila, high tech and others according to the EPZ's internal classification system. The estimated coefficient for the foreign dummy is 14.4 , with standard error $8.23(\mathrm{t}=1.75)$. Note that for our small sample size, the estimates are significant at $10 \%$.
} 


\section{6 - Discussion: linkages versus the empirical literature on MNCs and externalities}

The previous section shows that MNCs have a higher linkage coefficient than domestic firms in Brazil, Venezuela and Chile (at least when using the linkage coefficient with the total number of employees rather than the number of skilled employees in the denominator). According to the model presented in Section 4, this should lead to a positive backward linkage effect. However, in contrast to what has sometimes been implied in the empirical literature on FDI externalities, a positive backward linkage effect does not necessarily imply a positive externality from MNCs to suppliers. In fact, such a positive linkage effect should be leading to a positive externality from MNCs to other firms in the same industry (i.e., a positive horizontal externality). There is thus a puzzle, in that the empirical literature finds exactly the opposite: a negative or zero horizontal externality and a positive vertical externality. This section discusses this apparent contradiction between the implication of our findings and the general conclusions of the recent empirical literature on FDI externalities.

Could positive backward linkages lead to higher productivity for suppliers? In the model presented in Section 4, the Dixit-Stiglitz-Ethier specification implies that all that happens when demand for intermediate goods increases is that new suppliers enter the market and variety expands, conferring advantages of specialization on downstream producers. Suppliers would not be able to expand production, so they would not benefit from economies of scale. Generalizing beyond the Dixit-Stiglitz-Ethier specification, if the elasticity of substitution is not constant or if there is an endogenous mark-up (Eckel, 2003), it is possible that as demand for inputs increases, then both input variety and scale of production for suppliers increase, allowing them to reap productivity gains as they go down their average cost curve. These productivity gains, however, would not show up as increases in total factor productivity in most recent empirical studies, since they allow for the existence of increasing returns to scale. Thus, the falling average cost caused by a higher scale of production would be captured as gains from economies of scale rather than showing up in the residual.

This reasoning leads us to look for an alternative interpretation of the recent empirical finding of a positive externality from MNCs to suppliers. Rather than being 
evidence for backward linkages, this could point to the existence of positive knowledge spillovers, which would clearly lead to higher TFP among suppliers. Although there is plenty of anecdotal evidence for such knowledge spillovers (Lateef, 1997; Cynh, 1999) interviews we conducted with suppliers and MNCs in Costa Rica revealed few cases where it was clear that there had been a positive technology transfer from the MNC to suppliers. ${ }^{37}$ According to one of the MNCs we interviewed, this is because MNCs often do not have technical knowledge about the production process of the inputs they use. The cases where they do have such knowledge are usually related to sophisticated inputs that are physically integrated in the good being produced by the MNC; in these cases, however, it is unlikely that local firms will be able to supply these inputs, which are usually obtained by the MNCs from specialized international suppliers.

Instead of examples of knowledge spillovers, the interviews we conducted revealed many cases where suppliers had improved their technologies because of the pressures exerted on them by MNCs. ${ }^{38}$ That is, instead of stories of MNCs helping suppliers to improve their productivity through the transfer of technology, what we found were stories of how local firms had decided to upgrade the quality of their production process in order to become MNC suppliers. This suggests a different kind of linkage than the one we modeled in Section 4. Imagine that suppliers can choose to become highquality suppliers, but that this entails some investment. They will make this investment only if the demand for high-quality inputs is sufficiently large. Defining the qualitylinkage coefficient as the usage of high-quality inputs per employee, a modification of our model in Section 4 would show that if MNCs have a higher quality-linkage coefficient than domestic firms, then a stronger MNC presence would lead to a positive quality-linkage effect. Such an effect would imply an increase in the variety of highquality inputs produced locally and this would lead to an increase in productivity of domestic firms in downstream sectors. More interestingly, it is likely that the quality

\footnotetext{
${ }^{37}$ Rhee, Ross-Larson and Pursell (1984) reports of considerable knowledge transfer from foreign firms to Korean firms: visits to foreign plants by local staff and by foreign buyers to their plants; provision of blue prints an specifications, feedback on designs, quality and technical performance of their products. For example, Daewood Electronics (DE) entered an original equipment manufacturing arrangement with Japan's NEC in 1981. NEC enhanced DE's capability by providing technological help, see Cyhn (1999).

${ }^{38}$ This is consistent with the findings in the literature on industry upgrading in manufacturing value chains (see Humphrey and Schmitz, 2002).
} 
upgrading by suppliers would be captured as an increase in their measured TFP, providing an explanation for the observed positive productivity externality from MNCs to suppliers.

The question that remains is why we do not observe a positive externality from MNCs to other firms in the same industry. ${ }^{39}$ This is a problem not only for the two types of linkage effects we have described (one affecting the variety of inputs and the other affecting their quality), but also for any other type of positive externality from MNCs to suppliers. For instance, if MNCs generate knowledge spillovers to suppliers, one would expect this to lead to improvements in the quality of the inputs they produce, and this in turn to show up as increases in TFP for downstream firms. ${ }^{40}$ In other words, independently of the interpretations we suggest in this paper, the joint finding in the recent empirical literature of positive vertical externalities and negative horizontal externalities poses a puzzle.

The natural answer to this puzzle is that there must be some negative horizontal externality that more than compensates the positive effect that MNCs would have on other firms in the same industry through the increases in the variety and quality of domestic inputs they help to bring about. Such a negative horizontal productivity externality could be the result of a competition effect caused by the entry of MNCs, as argued by Aitken and Harrison (1999). If the entry of MNCs shrinks the market for domestic firms, this would most likely show up as a reduction in measured TFP because of the inability of the econometrician to adjust the measured capital stock for the reduction in its usage. Another mechanism through which negative horizontal productivity externalities could materialize is that MNCs could steal away the best

\footnotetext{
${ }^{39}$ Note that, as stated in footnote 22 , the model we presented implies that the externality benefits domestic firms in all sectors, not just in the sector of the multinational. To be more closely aligned with the empirical literature, we would have to adopt a different assumption, where intermediate goods are sector specific, so that only firms in the multinationals sector benefit from the backward linkages created. However, with our interpretation, where intermediate goods are not sector specific, there is no reason why - controlling for productivity growth in the whole manufacturing sector - productivity should increase in domestic firms in sector $\mathrm{j}$ when multinational presence in that sector increases. Thus, our interpretation may be more consistent with the results arising from the recent empirical literature.

${ }^{40}$ The case could be made that the knowledge spillover from MNCs to supplier leads to a decrease in input prices, which benefits downstream producers, but is captured as increases in materials usage, and hence does not show up as TFP growth. Still, one would expect an important part of spillovers to be improvements in quality rather than price reductions. Such quality improvements on the part of suppliers would most likely imply increases in measured TFP of downstream firms.
} 
workers from domestic firms. The problem here is that there is no formal theory showing how this may take place. ${ }^{41}$

\section{7 - Conclusion}

In recent years there has been a surge of empirical studies exploring the existence of productivity externalities from multinationals to other firms in their host countries. This research suggests that firms producing similar goods as multinationals are less likely to benefit from these externalities than firms in upstream industries. In fact, one of the most surprising conclusions to emerge from this literature is that multinationals may generate negative horizontal externalities. This is all the more surprising because the existence of positive externalities benefiting upstream industries should somehow have a ripple effect and benefit local firms using the same inputs as multinationals.

In this paper, we have focused on backward linkages as one particular mechanism through which externalities from multinationals may materialize. We have shown that by using the local sourcing coefficient as a measure of a firm's linkage potential, the current literature may be incorrectly implying that multinationals are likely to have a negative backward linkage effect. Using our alternative indicator of a firm's linkage potential, which takes into account the fact that multinationals are likely to use more inputs per unit of labor than domestic firms, we find that the opposite is true: multinationals are likely to have a positive linkage effect.

As we have stressed in the paper, however, there are several reasons why this result has to be interpreted with caution. First, taking into account differences in the skill mix of workers hired by MNCs and domestic firms leads to weaker results, where all we can say is that there is no evidence that multinationals linkage effect is negative. Second, very preliminary results using data from the Export Processing Zone system in Costa Rica suggests that the inputs bought locally by MNCs are more tradable than those bought by domestic firms. This would imply that the benefits of the linkages generated by MNCs are weaker than for domestic firms. Finally, data constraints have prevented us

\footnotetext{
${ }^{41}$ Hanson (2001) shows how competition for skilled workers may negatively affect domestic firms, but he does not show how this would affect their measured productivity.
} 
from exploring the role of other key assumptions of the model (e.g., increasing returns and the elasticity of substitution) on the difference between the implied linkage coefficient of MNCs and local firms. Clearly, much more research is required into these and other matters to clarify the impact of MNCs on host countries through linkages.

Even taking our results as convincing at this stage, it is not clear that incentives to MNCs are warranted. Perhaps a more sensible policy is to eliminate the barriers that prevent local firms from establishing adequate linkages. This includes improving local firms' access to inputs, technology, and financing, and streamlining the procedures associated with selling inputs to firms in Export Processing Zones.

A final comment relates to the observation that a strict interpretation of our model leads to the conclusion that multinationals' positive linkage effect should be reflected in a positive horizontal externality rather than the commonly found externality from multinationals to suppliers. This stands in direct contradiction with the results of the recent empirical literature. We argued that a different interpretation of the model, where backward linkages lead to quality improvements rather than variety expansion in upstream industries, should make the model consistent with the finding of positive vertical externalities. But the implication of a positive horizontal externality remains a puzzle for both interpretations of the model, as well as for theories where vertical externalities occur through knowledge spillovers.

There are two ways to think about this puzzle. One is that the empirical finding of a negative productivity externality from multinationals to firms in the same industry may be due to problems with the measurement of productivity or with the econometrics for dealing with the endogeneity of the presence of multinationals. Another way to think about the puzzle is that there may be some other source of negative productivity externality that compensates any positive ripple effect coming from the positive vertical externalities associated with multinationals. Exploring these two possibilities further is an important topic for future research. 


\section{Appendix A}

In this appendix we derive a sufficient condition for the LHS of equation (4) to be decreasing in $\mathrm{n}$. First, note that we can expand this term into two components:

$$
\begin{aligned}
& (\alpha / n) \sum_{j} w_{j}(n)\left(v(j)\left(\bar{L}_{j}-L_{j m}\right)+\gamma(j) \sigma_{j}(n)^{1 / \tilde{\beta}(j)} \tilde{v}(j) L_{j m}\right)= \\
& \sum_{j} v(j)\left(\bar{L}_{j}-L_{j m}\right)(\alpha / n) w_{j}(n)+\sum_{j} \gamma(j) \sigma_{j}(n)^{1 / \tilde{\beta}(j)} \tilde{v}(j) L_{j m}(\alpha / n) w_{j}(n)
\end{aligned}
$$

The first component is decreasing by our assumption that $v(j)<\theta$ for all $\mathrm{j}$. As to the second term, recall that $\sigma_{j}(n)$ is the ratio of the price of good $\mathrm{j}$ to the minimum unit cost of multinationals. Using the fact that in equilibrium domestic firms producing good $\mathrm{j}$ make zero profits, it is easy to show that:

$$
\sigma_{j}(n)=\psi_{j}\left(\frac{P_{x}(n)}{P_{x m}(n)}\right)^{1-\beta(j)}\left(\frac{w_{j}(n)}{P_{x m}(n)}\right)^{\beta(j)-\tilde{\beta}(j)}
$$

where $\psi$ is some constant dependent on $\beta(j)$ and $\tilde{\beta}(j)$ and where $P_{x}(n)=\alpha^{-1} n^{-1 / \theta}$ and $P_{x}(n)=\left(C+P_{x}(n)^{-\theta}\right)^{-1 / \theta}$ are the shadow prices of the composite intermediate good $\mathrm{X}$ for domestic firms and multinationals, respectively. It is easy to show that $P_{x}(n) / P_{x m}(n)$ is decreasing in $\mathrm{n}$. Thus, all we need is a sufficient condition for the term $\left(w_{j}(n) / n\right)\left(w_{j}(n) / P_{x m}(n)\right)^{\beta(j)-\tilde{\beta}(j)}$ to be decreasing in $\mathrm{n}$. Given that $P_{x}(n) / P_{x m}(n)$ is decreasing in $\mathrm{n}$, it is sufficient to find a condition for the term $\left(w_{j}(n) / n\right)\left(w_{j}(n) / P_{x}(n)\right)^{\beta(j)-\tilde{\beta}(j)}$ to be decreasing. But given that $P_{x}(n)=\alpha^{-1} n^{-1 / \theta}$, then:

$$
\left(p_{j}{ }^{1 / \beta(j)} \alpha^{v(j)} n^{\nu(j) / \theta-1}\right)\left(p_{j}^{1 / \beta(j)} \alpha^{\nu(j)+1} n^{(\nu(j)+1) / \theta}\right)^{\beta(j)-\tilde{\beta}(j)}=\xi n^{\nu(j) / \theta-1+(\beta(j)-\tilde{\beta}(j))(v(j)+1) / \theta}
$$

where $\xi$ is some constant. Some manipulation shows that:

$$
v(j) / \theta-1+(\beta(j)-\tilde{\beta}(j))(v(j)+1) / \theta=(1 / \theta)\left(\frac{1-\tilde{\beta}(j)}{\beta(j)}\right)-1
$$


Hence, if $\left(\frac{1-\tilde{\beta}(j)}{\beta(j)}\right)<\theta$ for all $\mathrm{j}$, then the LHS of equation (4) is decreasing in $\mathrm{n}$. Noting that $\left(\frac{1-\tilde{\beta}(j)}{\beta(j)}\right)<\left(\frac{1-\tilde{\beta}(j)}{\tilde{\beta}(j)}\right)$, we finally obtain the sufficient condition in the text.

\section{Appendix B}

In this appendix we show the procedure we follow to derive the quantitative significance of the regression results in section 5.3. To do so, we want to derive an expression for $\partial \ln w_{s} / \partial \ln L_{i m}$, where s is some sector possibly different from i. Since we are interested only in gauging the order of magnitude of this term, we will assume that $\beta(j)=\beta$ (and hence $v(j)=v$ ) for all $\mathrm{j}$ and also that we start out in a situation where $L_{j m}=\eta L_{j}$ for all $j$. Moreover, we will ignore the second order element associated with the impact of changing variety on the intensity coefficient of multinationals. This entails disregarding the derivative of $\sigma_{j}(n)$ with respect to $\mathrm{n}$. Thus, we can substitute $\lambda(j)$ for $\gamma(j) \sigma_{j}{ }^{1 / \tilde{\beta}(j)} \tilde{v}(j)$ in expression (4). Using $w_{j}(n)=p_{j}{ }^{1 / \beta(j)} \alpha^{v(j)} n^{v(j) / \theta}$ we then arrive at the following equation that determines equilibrium $\mathrm{n}$ :

$$
\sum_{j} \alpha p_{j}^{1 / \beta} \alpha^{v} n^{v / \theta-1}\left(v\left(\bar{L}_{j}-L_{j m}\right)+\lambda(j) L_{j m}\right)=\theta
$$

This implies that:

$$
n=\left(\frac{\theta}{\sum_{j} p_{j}{ }^{1 / \beta} \alpha^{v+1}\left(v\left(\bar{L}_{j}-L_{j m}\right)+\lambda(j) L_{j m}\right)}\right)^{\frac{1}{v / \theta-1}}
$$

Differentiating and simplifying, we obtain:

$$
\frac{\partial \ln n}{\partial L_{i m}}=\left(\frac{\theta}{\theta-v}\right)\left(\frac{\alpha w_{i} \lambda(i)-\alpha w_{i} v}{\sum_{j}\left(\alpha w_{j} v\left(\bar{L}_{j}-L_{j m}\right)+\alpha w_{j} \lambda(j) L_{j m}\right)}\right)
$$

Using our assumption that $L_{j m}=\eta L_{j}$ for all $j$ and manipulating the resulting expression we obtain: 


$$
\frac{\partial \ln n}{\partial \ln L_{i m}}=\left(\frac{\theta}{\theta-v}\right)\left(\frac{\alpha w_{i} \lambda(i)-\alpha w_{i} v}{\left(\bar{L} / \eta \bar{L}_{i}\right) \sum_{j}\left(\alpha w_{j} v(1-\eta)\left(\bar{L}_{j} / \bar{L}\right)+\alpha w_{j} \lambda(j) \eta\left(\bar{L}_{j} / \bar{L}\right)\right)}\right)
$$

where $\bar{L} \equiv \sum_{j} \bar{L}_{j}$. Letting $\omega_{j} \equiv \bar{L}_{j} / \bar{L}$, then:

$$
\frac{\partial \ln n}{\partial \ln L_{i m}}=\left(\frac{\theta}{\theta-v}\right) \eta \omega_{i}\left(\frac{\alpha w_{i} \lambda(i)-\alpha w_{i} v}{\sum_{j} \alpha w_{j} v \omega_{j}+\eta \sum_{j} \omega_{j}\left(\alpha w_{j} \lambda(j)-\alpha w_{j} v\right)}\right)
$$

Letting $l \equiv \alpha w_{i} \lambda(i)-\alpha w_{i} \nu$, which is common across sectors, then:

$$
\frac{\partial \ln n}{\partial \ln L_{i m}}=\left(\frac{\theta}{\theta-v}\right) \eta \omega_{i}\left(\frac{l}{\sum_{j} \alpha w_{j} v \omega_{j}+\eta l}\right)
$$

It is actually more instructive and useful to express this as follows:

$$
\frac{\partial \ln n}{\partial\left(L_{i m} / L_{i}\right)}=\left(\frac{\theta}{\theta-v}\right) \omega_{i}\left(\frac{l}{\sum_{j} \alpha w_{j} v \omega_{j}+\eta l}\right)
$$

To proceed, empirical estimates of the elasticity of substitution among intermediate goods revolve around 4 (see Feenstra, 1994), which implies that $\alpha=1-1 / 4=3 / 4$. In turn, this implies that $\theta=\frac{\alpha}{1-\alpha}=3$.

We can obtain $\eta$ directly from the data. For $v$, we experimented with two values. We first assumed $\beta=1 / 2$, which implies $v=\frac{1-\beta}{\beta}=1$. Alternatively, for each domestic firm, we have data on the wages paid and also on the linkage coefficient for domestic firms (the total value of inputs bought domestically per unit of labor hired), which corresponds to $\alpha w_{i} v$. In order to obtain an average parameter value for $v$, we estimated the following relation Linkage Coefficient $i j t=A_{0}+A_{1}$ AverageWages $_{i j t}+\varepsilon_{i j t}$. We use the resulting estimate for $A_{1}$ to obtain $v$ from $v=A_{1} / \alpha$. Given $\alpha=0.75$, for the case of Venezuela, for example, the estimated value of $v$ was 2.3 , which in turn implies $\beta=0.3$. 
$\eta$ corresponds to the share of workers hired by multinationals; and $\varpi_{i}$ the share of workers in sector $i$. Employment data was taken from the corresponding Annual Industry Survey.

$l=\alpha w_{i} \lambda(i)-\alpha w_{i} v$, the difference between the total value of inputs bought domestically per unit of labor hired by multinationals and domestic firms, respectively, corresponds to the estimated coefficient for the foreign dummy in equation (5).

For the value of inputs bought domestically per unit of labor hired by the domestic firm in sector i, $\alpha w_{i} v$, we used the corresponding estimated value of the sector dummies plus the effect for the base year (the first year in each of the data sets) in (5). Hence, the estimated elasticities correspond the first year in each data set. We multiplied the value $\alpha w_{i} v$ by the share of workers in each sector $i, \varpi_{i}$. We finally added the terms across all sectors and added $\eta l$ to obtaining the term in the denominator, $\sum_{j} \alpha w_{j} v \varpi_{j}+\eta l$.

Finally, the corresponding elasticity for wages is given by $\frac{\partial \ln w_{s}}{\partial\left(L_{i m} / L_{i}\right)}=\left(\frac{\theta}{v}\right) \frac{\partial \ln n}{\partial\left(L_{i m} / L_{i}\right)}$. In the text, we report average results for $v=1$. In the case of Venezuela, for example, the estimated values for $\frac{\partial \ln w_{s}}{\partial\left(L_{i m} / L_{i}\right)}$ in 1995 for each sector of the 9 manufacturing sectors according to 2 digit-ISIC2 classification correspond to $0.60 \%$, $0.27 \%, 0.05 \%, 0.15 \%, 0.47 \%, 0.18 \%, 0.26 \%, 0.43 \%$, and $0.03 \%$. 


\section{9 - References}

Aitken, B., A. Harrison and R. E. Lipsey, 1996. "Wages and Foreign Ownership: A Comparative Study of Mexico, Venezuela and the Unites States," Journal of International Economics 40, 345-371.

Aitken, B. J. and A. Harrison, 1999. "Do Domestic Firms Benefit from Direct Foreign Investment? Evidence from Venezuela," American Economic Review 89, 605618.

Alfaro, L., A. Chanda, S. Kalemli-Ozcan and S. Sayek, 2003. "FDI and Economic Growth, The Role of Local Financial Markets," Journal of International Economics, forthcoming.

Antweiler, W. and D. Trefler, 2000. "Increasing Returns and All that: A View from Trade,” NBER Working Paper 2941.

Arellano, M. and O. Bover, 1995. "Another Look at Instrumental Variable Estimation of Error-Components Model," Journal of Econometrics 68, 29-52.

Barry, F. and Bradley, J., 1997. "FDI and Trade: the Irish Host-Country Experience," Economic Journal 107, 1798-1811.

Biersteker, T. J. (1978). Distortion or Development: Contending Perspectives on the Multinational Corporation. Cambridge, MA: MIT Press.

Blalock, G. and P. Gertler, 2003, "Technology from Foreign Direct Investment and Gains through the Supply Chain," mimeo.

Blomstrom, M., 1983. Foreign Investment and Spillovers, Routledge London and New York.

Blomstrom, M. and A. Kokko, 1998. "Multinational Corporations and Spillovers," Journal of Economic Surveys 12, 247-277.

Blomstrom, M. and A. Kokko, 2003. "The Economics of Foreign Direct Investment Incentives," NBER Working Paper 9489.

Blomstrom, M. and E. N. Wolff, 1994. "Multinational Corporations and Productivity Convergence in Mexico," in William Baumol, Richard Nelson and Edward N. 
Wolff, Editors, Convergence of Productivity: Cross-national Studies and Historical Evidence, Oxford: Oxford University Press.

Borensztein, E., J. De Gregorio, and J-W. Lee, 1998. "How Does Foreign Direct Investment Affect Economic Growth?" Journal of International Economics 45, 115-135.

Carkovic, M. and R. Levine, 2002. "Does Foreign Direct Investment Accelerate Economic Growth?" University of Minnesota, Working Paper.

Branstetter, L., 2000. "Is Foreign Direct Investment A Channel of Knowledge Spillovers? Evidence from Japan's FDI in the United States,” NBER Working 8015.

Caves, R., 1974. "Multinational Firms, Competition and Productivity in the Host Country," Economica 41, 176-193.

Caves, R., 1996. Multinational Enterprise and Economic Analysis. Cambridge, England: Cambridge University Press.

Chen, E.K.Y., 1983. Multinational Corporations, Technology and Employment. Macmillan, London.

Cohen, B., 1973. "Comparative Behavior of Foreign and Domestic Export Firms in a Developing Economy," Review of Economics Statistics 55, 190-197.

Cynn, J. W., 1999. "The Political Economy of Technical Learning: A Case Study of Korea's Electronic Industry', University of Oxford, unpublished dissertation mimeo.

Djankov, S. and B. Hoekman, 2000. "Foreign Investment and Productivity Growth in Czech Enterprises," World Bank Economic Review 14, 49-64.

Ellison, G. and E. Glaeser, 1999. "The Geographic Concentration of Industry: Does Natural Advantage Explain Agglomeration?," American Economic Review 89, 311-316.

, 1997. "Geographic Concentration in U.S. Manufacturing Industries: A Dartboard Approach," Journal of Political Economy 105, 889-927. 
Eckel, C., 2003. "Does globalization lead to specialization?", manuscript, Department of Economics, University of Göttingen.

Ethier, W., 1982. "National and International Returns to Scale in the Modern Theory of International Trade," American Economic Review 72, 389-405.

Fallick, B., C.A. Fleischman and J. B. Rebitzer, 2003. "Job Hopping in Silicon Valley: The Micro-Foundations of a High Technology Cluster," mimeo.

Feenstra, R.C., 1994. "New Product Varieties and the Measurement of International Prices," American Economic Review 84, 157-177.

Forsyth, D.J.C., 1972. “US Investments in Scotland,” New York: Preager.

Fosfuri A., M. Motta and T. Ronde, 2001. "Foreign Direct Investment and Spillovers through Workers' Mobility," Journal of International Economics 53, 205-222.

Fujita, M., P. Krugman and A.J. Venables, 1999. The Spatial Economy: Cities, Regions and International Trade. Cambridge: MIT Press.

Gerschenberg, I., 1987. "The Training and Spread of Managerial Know-how. A Comparative Analysis of Multinationals and Other Firms in Kenya," World Development 15, 931-939.

Girma, S., D. Greenaway and K. Wakelin, 1999. "Wages, Productivity and Foreign Ownership in UK Manufacturing," Working paper, Center for Research on Globalisation and Labour markets, University of Nottingham.

Gorg, H. and E. Strobl, 2002, "Multinational Companies and Indigenous Development: An Empirical Analysis," European Economic Review, 46, 1305-1322

Gorg, H. and D. Greenaway, 2002, "Much Ado About Nothing? Do Domestic Firms Really Benefit from Foreign Direct Investment?, CEPR Discussion Paper 3485.

Gorg, H. and F. Ruane, 2001, "Multinational Companies and Linkages: Panel-Data Evidence for the Irish Electronics Sector," International Journal of the Economics and Business 1, 1-18.

Grossman, G., and E. Helpman, 1992. Innovation and Growth in the Global Economy. Cambridge: MIT Press. 
Hanson, G. H., 2001. "Should Countries Promote Foreign Direct Investment?" G-24 Discussion Paper No. 9. New York: United Nations.

, 2000. "Scale Economics and the Geographic Concentration of Industry," NBER Working Paper 8013.

Haddad, M. and A. Harrison, 1993. "Are There Positive Spillovers from Direct Foreign Investment?" Journal of Development Economics 42, 51-74.

Haskel, J. E., S. C. Pereira and M. J. Slaughter, 2002. "Does Inward Foreign Direct Investment Boost the Productivity of Local Firms?” NBER Working Paper 8433.

Helpman, E. and P. Krugman, 1985. Market Structure and Foreign Trade: Increasing Returns, Imperfect Competition, and the International Economy. Cambridge: MIT Press.

Hirschman, A., 1958. The Strategy of Economic Development. New Haven: Yale University Press.

Hummels, D., 1999. “Toward a Geography of Trade Costs," working paper, Purdue University. , 2001. “Time as a Trade Barrier,” working paper, Purdue University.

Hummels, D. and P. Klenow, 2002. "The Variety and Quality of a Nation's Exports," mimeo.

Humphrey, J. and H. Schmitz, 2002. "Developing Country Firms in the World Economy: Governance and Upgrading in Global Value Chains," INEF Report, No. 61, Duisburg: University of Duisburg.

Javorcik, B. S., B., 2003. "Does Foreign Direct Investment Increase the Productivity of Domestic Firms? In Search of Spillovers Through Backward Linkages," American Economic Review, forthcoming.

Katayama, H., S. Lu and J. R. Tybout, 2003. "Why Plant-Level Productivity Studies are Often Misleading, and an Alternative Approach to Inference," NBER Working Paper 9617. 
Klenow, P. and A. Rodríguez-Clare, 1997. "Quantifying Variety Gains from Trade Liberalization," mimeo.

Kokko, A., 1994. "Technology, Market Characteristics and Spillovers," Journal of Development Economics 43, 279-293.

Kokko, A., M. Zejan and R. Tansini, 1994. "Trade Regime and Spillover Effects of FDI: Evidence from Uruguay," Review of World Economics 137, 124-49.

Kugler, M., 2001. "The Diffusion of Externalities from Foreign Direct Investment: The Sectoral Pattern of Technological Spillovers," mimeo.

Larraín, F., Lopéz-Calva, L., Rodríguez-Clare, A., 2000. "Intel: A Case Study of Foreign Direct Investment in Central America." Center for International Development, Harvard University Working Paper No. 58.

Lall, S., "Vertical Inter-Firm Linkages in LDCs: An Empirical Study," Oxford Bulletin of Economics and Statistics 42, 203-206.

Lateef, A., 1997. "Linking up with the global economy: a case study of the Bangladore software industry," Discussion paper no Db-97-1997, International Institute of Labou Sudies.

Lindsey, C.W., 1986. "Transfer of technology to the ASEAN region by U.S. transnational corporations," ASEAN Economic Bulleting 3, 225-247.

Lipsey, R. E., 2002. "Home and Host Country Effects of FDI," NBER Working Paper 9293.

Lipsey, R. E. and F. Sjoholm, 2001. "Foreign Direct Investment and Wages in Indonesian Manufacturing,” NBER Working Paper 8299.

Lipsey, R. E. and F. Sjoholm, 2002. "Foreign Direct Investment and Indonesian Manufacturing Wages: An Analysis with Panel Data," NBER Working Paper 9417.

López-Córdova, J.E., 2003, "NAFTA and Manufacturing Productivity in Mexico," mimeo. 
Markusen, J. 1995. "The Boundaries of Multinational Enterprises and the Theory of International Trade," Journal of Economic Perspectives 9, 169-89.

Markusen. J. and A.J. Venables, 1999. "Foreign Direct Investment as a Catalyst for Industrial Development," European Economic Review 43, 335-338.

McAlesse, D., and D. McDonald, 1978. "Employment Growth and the Development of Linkages in Foreign-Owned and Domestic Manufacturing Enterprises," Oxford Bulletin of Economics and Statistics 40, 321-339.

Olley, S. and A. Pakes, 1996. "The Dynamics of Productivity in the Telecommunications Equipment Industry," Econometrica 64, 1263-1297.

O'Loughlin, B. and P.N. O'Farrel, 1980. "Foreign Direct Investment in Ireland: Empirical Evidence and Theoretical Implications," The Economic and Social Review 11, 155-185.

Overman, H., S. Redding and A. Venables (2001), The Economic Geography of Trade, Production and Income: A Survey of Empirics, CEPR Discussion Paper No. 2978.

Pack, H., 1997. "The Role of Exports in Asian Development," in Nancy Birdsall and Frederick Jaspersen, ed., Pathways to Growth: Comparing East Asia and Latin American. Washington D.C.: Inter-American Development Bank

Porter, M., 1990. "The Competitive Advantage of Nations," Free Press.

Pavcnik, N., 2001. "Trade Liberalization, Exit and Productivity Improvements: Evidence from Chilean Plants," Review of Economics Studies, forthcoming.

Rhee, Y., Ross-Larson, B., Pursell, G., 1984. Korea's Competitive Edge: Managing Entry into World Markets. Johns Hopkins Univ. Press, Baltimore.

Ritchie, B., Zhuang, L. and Whitworth, T., 2001. "Experiences of JV Companies in China: Management and Operational issues," in Thorp, R. and Little, S., Global Change: The Impact of Asia in the $21^{\text {st }}$ century.

Rodríguez-Clare, A., 1993. The Division of Labor, Agglomeration Economies and Economic Development, Ph. D. Dissertation, Stanford University. 
, 1996. "Multinationals, Linkages and Economic Development." American Economic Review 86, 852-873.

, 1996. "The Division of Economic Development," Journal of Development Economics, Vol. 49, No.1, pp. 1-32

Rodrik, D., 1995 “Getting Interventions Right: How South Korea and Taiwan Grew Rich," Economic Policy 0, 53-97.

Romer, P. M., 1990 “Endogenous Technological Change," Journal of Political Economy 98, S71-102.

Saggi, K., 2002. "Trade, Foreign Direct Investment and International Technology Transfer: A Survey," The World Bank Research Observer 17, 191-235.

Spar, D., 1998. “Attracting High Technology Investment: Intel's Costa Rica Plant," World Bank Occasional Paper 11.

Sjoholm, F., 1999. "Technology Gap, Competition and Spillovers from Direct Foreign Investment: Evidence from Establishment Data," Journal of Development Studies $36,53-73$.

Tybout, J., 2001. "Plant and Firm Level evidence on "New" Trade Theories," NBER Working Paper 8418.

Tybout, J. R. and D. M. Westbrook, 1995. "Trade Liberalization and the Dimensions of Efficiency Change in Mexican Manufacturing Industries," Journal of International Economics 39, 53-78.

UNCTAD, 2001. Trade and Investment Report. New York: The United Nations.

World Bank, 1995. The World Bank Development Report 1995, Workers in an Integrating World, Washington D.C., Oxford University Press, The World Bank.

Wells, L. T. Jr. and A. Wint, 2000. Marketing a Country: Promotion as a Tool for Attracting Foreign Investment, Foreign Investment Advisory Service, Occasional Paper No. 13, International Finance Corporation/Multilateral Investment Guarantee Agency, Washington, D.C. 
Xu, B., 2000. "Multinational Enterprises, Technology Diffusion, and Host Country Productivity Growth,” Journal of Development Economics 62, 477-493. 


\section{Table 1: Overview of Evidence on Spillovers from Foreign to Local Firms in Developing Countries}

\begin{tabular}{|c|c|c|c|}
\hline Author(s) & Sample & Results & Issues \\
\hline \multicolumn{4}{|l|}{$\underline{\text { Cross-Section }}$} \\
\hline $\begin{array}{l}\text { Blomstrom and } \\
\text { Wolff (1994) }\end{array}$ & Mexico, 1970 & $\begin{array}{l}\text { Higher foreign shares in an industry in } 1970 \text { led } \\
\text { to higher rates of productivity growth in locally } \\
\text { owned firms over the next five years. }\end{array}$ & \multirow{3}{*}{$\begin{array}{l}\text { Cross-sectional do not control } \\
\text { for time invariant differences in } \\
\text { productivity across sectors, } \\
\text { which might be correlated but } \\
\text { not caused by foreign presence. }\end{array}$} \\
\hline $\begin{array}{l}\text { Kokko, Zejan } \\
\text { and Tansini } \\
(2001)\end{array}$ & Uruguay, 1988 & $\begin{array}{l}\text { Positive spillovers from FDI to a sub-sample of } \\
\text { locally-owned manufacturing plants with } \\
\text { moderate technology gaps vis-a-vis foreign } \\
\text { firms. }\end{array}$ & \\
\hline Sjoholm (1999) & $\begin{array}{l}\text { Indonesia, } \\
1980-1991\end{array}$ & $\begin{array}{l}\text { Positive effects from FDI to locally owned } \\
\text { establishments. }\end{array}$ & \\
\hline \multicolumn{4}{|l|}{$\underline{\text { SUR estimation }}$} \\
\hline $\begin{array}{l}\text { Borensztein, De } \\
\text { Gregorio, Lee } \\
\text { (1998) }\end{array}$ & $\begin{array}{l}\text { FDI flows ind. } \\
\text { countries to } 69 \\
\text { LDC, 1970- } \\
1979 ; 1980-1989\end{array}$ & $\begin{array}{l}\text { FDI contributes to growth only when the host } \\
\text { country has a minimum threshold stock of } \\
\text { human capital. }\end{array}$ & $\begin{array}{l}\text { Estimation does not fully control } \\
\text { for simultaneity bias, country- } \\
\text { specific effects and the use of } \\
\text { lagged dependent variables in } \\
\text { growth regressions. }\end{array}$ \\
\hline \multicolumn{4}{|l|}{$\underline{\text { Panel }}$} \\
\hline $\begin{array}{l}\text { Haddad and } \\
\text { Harrison (1994) }\end{array}$ & $\begin{array}{l}\text { Morocco, } \\
1985-1989\end{array}$ & $\begin{array}{l}\text { Reject the hypothesis that foreign presence } \\
\text { accelerated productivity growth in domestic } \\
\text { firms. }\end{array}$ & \multirow{3}{*}{$\begin{array}{l}\text { Fixed-effect estimation do not } \\
\text { address the simultaneity bias that } \\
\text { results from the dependence of } \\
\text { factor inputs on productivity } \\
\text { levels and exit decisions. }\end{array}$} \\
\hline $\begin{array}{l}\text { Aitken and } \\
\text { Harison (1999) }\end{array}$ & $\begin{array}{l}\text { Venezuela, } \\
1976-1989\end{array}$ & $\begin{array}{l}\text { Small net impact of foreign investment. } \\
\text { Positive effect of foreign equity participation on } \\
\text { plant productivity robust only for small firms. } \\
\text { Negative effect foreign investment on } \\
\text { domestically owned plants. }\end{array}$ & \\
\hline $\begin{array}{l}\text { Djankov and } \\
\text { Hoekman }(2000)\end{array}$ & $\begin{array}{l}\text { Czech Republic, } \\
\text { 1992-1996 }\end{array}$ & $\begin{array}{l}\text { Joint ventures and foreign direct investment } \\
\text { have a negative spillover effect on firms that do } \\
\text { not have foreign partnerships. }\end{array}$ & \\
\hline \multicolumn{4}{|c|}{$\underline{\text { Panel - Olley-Pakes }}$} \\
\hline $\begin{array}{l}\text { Javorcik } \\
(2003)\end{array}$ & $\begin{array}{l}\text { Lithuania, } \\
1996-2000\end{array}$ & $\begin{array}{l}\text { No evidence horizontal spillovers, some } \\
\text { evidence backward spillovers. }\end{array}$ & \multirow{5}{*}{$\begin{array}{l}\text { In differentiated product } \\
\text { industries, sales revenues and } \\
\text { input expenditures are not good } \\
\text { proxies for physical outputs and } \\
\text { inputs, respectively; leading to } \\
\text { underestimation of productivity } \\
\text { measures. }\end{array}$} \\
\hline $\begin{array}{l}\text { Blalock and } \\
\text { Gerter (2003) }\end{array}$ & $\begin{array}{l}\text { Indonesia, } \\
1988-1996\end{array}$ & Strong evidence for backward spillovers. & \\
\hline $\begin{array}{l}\text { López-Córdova } \\
\text { (2003) }\end{array}$ & $\begin{array}{l}\text { Mexico, } \\
1993-2000\end{array}$ & $\begin{array}{l}\text { Foreign capital improves (TFP); positive inter- } \\
\text { industry spillovers form FDI prevail over a } \\
\text { negative intra-industry effect }\end{array}$ & \\
\hline \multicolumn{3}{|l|}{$\underline{\mathrm{GMM}}$} & \\
\hline $\begin{array}{l}\text { Carkovic and } \\
\text { Levine (2002) }\end{array}$ & $\begin{array}{l}72 \text { countries, } \\
1960-1995 \\
5 \text { year-periods }\end{array}$ & $\begin{array}{l}\text { Exogenous component of FDI does not exert a } \\
\text { robust, positive influence on economic growth. }\end{array}$ & \\
\hline
\end{tabular}




\begin{tabular}{|c|c|c|c|c|c|c|c|c|c|c|c|c|c|c|}
\hline & & & & & & & & & & & & & & $\underline{\text { Mean }}$ \\
\hline Brazil & 1997 & 1998 & 1999 & 2000 & & & & & & & & & & \\
\hline Foreign & 72541 & 60578 & 41043 & 44405 & & & & & & & & & & 55320 \\
\hline Local & 38427 & 43956 & 29012 & 25821 & & & & & & & & & & 34847 \\
\hline Venezuela & 1995 & 1996 & 1997 & 1998 & 1999 & & & & & & & & & \\
\hline Foreign & 3920 & 5566 & 10303 & 18805 & 14558 & & & & & & & & & 9818 \\
\hline Local & 3829 & 5833 & 9085 & 12262 & 10411 & & & & & & & & & 7900 \\
\hline Mexico & 1993 & 1994 & 1995 & 1996 & 1997 & 1998 & 1999 & 2000 & & & & & & \\
\hline Foreign & 101 & 117 & 154 & 222 & 236 & 257 & 288 & 402 & & & & & & 217 \\
\hline Local & 98 & 113 & 202 & 264 & 322 & 359 & 336 & 351 & & & & & & 247 \\
\hline Chile & 1987 & 1988 & 1989 & 1990 & 1991 & 1992 & 1993 & 1994 & 1995 & 1996 & 1997 & 1998 & 1999 & \\
\hline Foreign & 3569 & 12926 & 14908 & 16864 & 19488 & 22190 & 23892 & 28700 & 20454 & 20833 & 22542 & 25441 & 27249 & 15803 \\
\hline Local & 2723 & 3117 & 3622 & 4219 & 5387 & 5975 & 6528 & 7012 & 8766 & 9472 & 10564 & 11577 & 15343 & 7263 \\
\hline
\end{tabular}

Notes: The average linkage coefficient was calculated as the average value of domestic inputs to total workers per year for foreign and domestic firms respectively. Data in local currency, for Venezuela in thousands. Data are from the respective country annual industrial surveys of plants.

Table 2b: Average Share of Domestic Inputs to Total Inputs by Year and Firm Ownership

\begin{tabular}{|c|c|c|c|c|c|c|c|c|c|c|c|c|c|c|}
\hline & & & & & & & & & & & & & & Mean \\
\hline Brazil & 1997 & 1998 & 1999 & 2000 & & & & & & & & & & \\
\hline Foreign & 0.705 & 0.685 & 0.671 & 0.662 & & & & & & & & & & 0.682 \\
\hline Local & 0.933 & 0.934 & 0.934 & 0.933 & & & & & & & & & & 0.933 \\
\hline Venezuela & 1995 & 1996 & 1997 & 1998 & 1999 & & & & & & & & & \\
\hline Foreign & 0.759 & 0.830 & 0.783 & 0.698 & 0.824 & & & & & & & & & 0.792 \\
\hline Local & 0.851 & 0.880 & 0.861 & 0.822 & 0.870 & & & & & & & & & 0.861 \\
\hline Mexico & 1993 & 1994 & 1995 & 1996 & 1997 & 1998 & 1999 & 2000 & & & & & & \\
\hline Foreign & 0.560 & 0.551 & 0.534 & 0.533 & 0.520 & 0.530 & 0.533 & 0.522 & & & & & & 0.536 \\
\hline Local & 0.854 & 0.847 & 0.855 & 0.853 & 0.835 & 0.842 & 0.835 & 0.820 & & & & & & 0.844 \\
\hline Chile & 1987 & 1988 & 1989 & 1990 & 1991 & 1992 & 1993 & 1994 & 1995 & 1996 & 1997 & 1998 & 1999 & \\
\hline Foreign & 0.915 & 0.882 & 0.896 & 0.893 & 0.894 & 0.883 & 0.874 & 0.874 & 0.756 & 0.724 & 0.702 & 0.759 & 0.767 & 0.874 \\
\hline Local & 0.914 & 0.927 & 0.933 & 0.935 & 0.933 & 0.923 & 0.920 & 0.912 & 0.919 & 0.921 & 0.921 & 0.923 & 0.936 & 0.923 \\
\hline
\end{tabular}


Table 2c: Average Intensity Coefficient by Year and Firm Ownership

\begin{tabular}{|c|c|c|c|c|c|c|c|c|c|c|c|c|c|c|}
\hline & & & & & & & & & & & & & & Mean \\
\hline Brazil & 1997 & 1998 & 1999 & 2000 & & & & & & & & & & \\
\hline Foreign & 100049 & 88433 & 65233 & 70070 & & & & & & & & & & 81684 \\
\hline Local & 43838 & 49549 & 33165 & 29853 & & & & & & & & & & 39700 \\
\hline Venezuela & 1995 & 1996 & 1997 & 1998 & 1999 & & & & & & & & & \\
\hline Foreign & 6146 & 8700 & 15779 & 28720 & 20164 & & & & & & & & & 14597 \\
\hline Local & 4704 & 7265 & 11674 & 16445 & 13368 & & & & & & & & & 10138 \\
\hline Mexico & 1993 & 1994 & 1995 & 1996 & 1997 & 1998 & 1999 & 2000 & & & & & & \\
\hline Foreign & 174 & 210 & 319 & 464 & 532 & 591 & 652 & 811 & & & & & & 457 \\
\hline Local & 120 & 138 & 246 & 324 & 405 & 444 & 417 & 445 & & & & & & 305 \\
\hline Chile & 1987 & 1988 & 1989 & 1990 & 1991 & 1992 & 1993 & 1994 & 1995 & 1996 & 1997 & 1998 & 1999 & \\
\hline Foreign & 4117 & 14426 & 16435 & 19011 & 22154 & 25410 & 27318 & 32819 & 27809 & 29035 & 33130 & 33590 & 38820 & 18731 \\
\hline Local & 3202 & 3575 & 4109 & 4752 & 6112 & 6913 & 7643 & 8348 & 10097 & 10818 & 11998 & 13117 & 16984 & 8299 \\
\hline
\end{tabular}

Notes: The average intensity coefficient was calculated as the average value of total inputs to total workers per year for foreign and domestic firms respectively. Data in local currency, for Venezuela in thousands. See notes to Table 1a for data sources. 


\section{Table 3: Linkage effects - Foreign Ownership}

Dependent variable - Linkage coefficient, firm $i$

(Value of inputs bought domestically to total workers)

\begin{tabular}{lcccc}
\hline \hline & Brazil & Chile & Mexico & Venezuela \\
\hline Foreign & $\begin{array}{c}20680 \\
(3.60)^{* * *}\end{array}$ & $\begin{array}{c}11442 \\
(9.18)^{* * *}\end{array}$ & $\begin{array}{c}-33.4 \\
(-1.28)\end{array}$ & $\begin{array}{c}1904 \\
\end{array}$ \\
Observations & 38926 & 65812 & 47065 & 13724 \\
$\mathrm{R}^{2}$ & 0.1 & 0.1 & 0.1 & 0.1 \\
\hline \hline
\end{tabular}

Notes: All regressions include annual time dummies and are estimated by OLS with White's correction of heteroskedasticity. $t$-statistics are in parentheses denoting $* * * 1 \%, * * 5 \%$, and $* 10 \%$ significance. Foreign is a dummy variable for foreign ownership.

Table 4a: Linkage effect - Foreign Ownership Controlling for Sectors

Dependent variable - Linkage coefficient, firm $i$

(Value of inputs bought domestically to total workers)

\begin{tabular}{lcccc}
\hline \hline & Brazil & Chile & Mexico & Venezuela \\
\hline Foreign & 15412 & 9218 & 8.9 & 1565 \\
& $(2.67)^{* * *}$ & $(7.36)^{* * *}$ & $(0.42)$ & $(1.84)^{*}$ \\
Observations & 38926 & 65812 & 47065 & 13724 \\
$\mathrm{R}^{2}$ & 0.1 & 0.1 & 0.1 & 0.1
\end{tabular}

Notes: All regressions include annual time dummies and industry dummies and are estimated by OLS with White's correction of heteroskedasticity. t-statistics are in parentheses denoting $* * * 1 \%, * * 5 \%$, and $* 10 \%$ significance. Foreign is a dummy variable for foreign ownership. For Chile, Mexico, and Venezuela, industry dummies correspond to two-digit ISIC2 classification; for Brazil two-digit ISIC 3 classification. 


\section{Table 4b: Share - Foreign Ownership Controlling for Sectors}

Dependent variable - Share of inputs sourced domestically, firm $i$

\begin{tabular}{lcccc}
\hline \hline & Brazil & Chile & Mexico & Venezuela \\
\hline Foreign & $\begin{array}{c}-0.391 \\
(-56.16)^{* * *}\end{array}$ & $\begin{array}{c}-0.274 \\
(-30.46)^{* * *}\end{array}$ & $\begin{array}{c}-0.401 \\
(-53.85)^{* * *}\end{array}$ & $\begin{array}{c}-0.171 \\
(-9.45)^{* * *}\end{array}$ \\
& & & \\
Observations & 38926 & 65720 & 44575 & 13555 \\
\hline \hline
\end{tabular}

Notes: All regressions include annual time dummies and industry dummies and are estimated using a Tobit model. $\mathrm{t}$ statistics are in parentheses denoting *** 1\%,**5\%, and * 10\% significance. See notes to tables $2 \mathrm{a}$ and $3 \mathrm{a}$ for definitions of the other variables.

\section{Table 4c: Intensity - Foreign Ownership Controlling for Sectors}

Dependent variable - Ratio of total inputs to workers, firm $i$

\begin{tabular}{lcccc}
\hline \hline & Brazil & Chile & Mexico & Venezuela \\
\hline Foreign & $\begin{array}{c}32834 \\
(5.01)^{* * *}\end{array}$ & $\begin{array}{c}11521 \\
(8.99)^{* * *}\end{array}$ & $\begin{array}{c}181.5 \\
(6.34)^{* * *}\end{array}$ & $\begin{array}{c}3929 \\
(4.08)^{* * *}\end{array}$ \\
Observations & 38926 & 65812 & 46692 & 13724 \\
$\mathrm{R}^{2}$ & 0.1 & 0.1 & 0.1 & 0.2 \\
\hline \hline
\end{tabular}

Notes: All regressions include annual time dummies and industry dummies and are estimated by OLS with White's correction of heteroskedasticity. $t$-statistics are in parentheses denoting $* * * 1 \%$, ** $5 \%$, and $* 10 \%$ significance. See notes to tables $2 \mathrm{a}$ and $3 \mathrm{a}$ for definitions of the other variables. 


\section{Table 5a: Linkage Effects - Age New Foreign Firms - Sectors \\ Dependent variable - Linkage coefficient, firm $i$ \\ (Value of inputs bought domestically to total workers)}

\begin{tabular}{|c|c|c|}
\hline & Mexico & Venezuela \\
\hline Foreign & $\begin{array}{l}11.0 \\
(0.49)\end{array}$ & $\begin{array}{c}1907 \\
(2.07)^{* *}\end{array}$ \\
\hline New Firms $\times$ Foreign & $\begin{array}{l}-35.0 \\
(-1.29)\end{array}$ & $\begin{array}{c}-3987 \\
(-3.13) * * *\end{array}$ \\
\hline Observations & 47065 & 13724 \\
\hline $\mathrm{R}^{2}$ & 0.1 & 0.1 \\
\hline
\end{tabular}

Notes: All regressions include annual time dummies and industry dummies and are estimated by OLS with White's correction of heteroskedasticity. t-statistics are in parentheses denoting $* * * 1 \%, * * 5 \%$, and $* 10 \%$ significance. New Firms is a dummy variable for firms with less than 3 years of age. See notes to tables $2 \mathrm{a}$ and $3 \mathrm{a}$ for definitions of the other variables.

\section{Table 5b: Share - Tobit Regression - Age New Foreign Firms - Sectors}

Dependent variable - Share of inputs sourced domestically, firm $i$

\begin{tabular}{lcc}
\hline \hline & Mexico & Venezuela \\
\hline Foreign & -0.396 & -0.183 \\
& $(-51.78)^{* * *}$ & $(-9.78)^{* * *}$ \\
New Firms $\times$ Foreign & -0.085 & 0.159 \\
& $(-2.94)^{* * *}$ & $(0.46)$ \\
Observations & & \\
\hline \hline
\end{tabular}

Notes: All regressions include annual time dummies and industry dummies and are estimated using a Tobit model. tstatistics are in parentheses denoting $* * * 1 \%, * * 5 \%$, and $* 10 \%$ significance. New Firms is a dummy variable for firms with less than 3 years of age. See notes to tables $2 \mathrm{a}$ and $3 \mathrm{a}$ for definitions of the other variables. 
Table 6: Share - Time Trend Foreign Firms

Dependent variable - Share of inputs sourced domestically, foreign firm $i$

\begin{tabular}{lcccc}
\hline \hline & Brazil & Chile & Mexico & Venezuela \\
\hline Time Trend & $\begin{array}{l}0.001 \\
(0.65)\end{array}$ & $\begin{array}{c}0.007 \\
(1.84)^{*}\end{array}$ & $\begin{array}{c}0.009 \\
(6.43)^{* * *}\end{array}$ & $\begin{array}{c}0.007 \\
(1.26)\end{array}$ \\
Observations & 3152 & 6223 & 4408 & 1508 \\
\# of Groups & 852 & 2339 & 551 & 818 \\
\hline \hline
\end{tabular}

Notes: All regressions include firm specific effects using a random effect Tobit model. z-statistics are in parentheses denoting $* * * 1 \%, * * 5 \%$, and $* 10 \%$ significance. Regressions include only foreign firms. See notes to tables $2 \mathrm{a}$ and $3 \mathrm{a}$ for definitions of the other variables.

Table 7: Average Wages

Dependent variable - Total wages to number of workers, firm $i$

\begin{tabular}{lcccc}
\hline \hline & Brazil & Chile & Mexico & Venezuela \\
\hline Foreign & $\begin{array}{c}7258 \\
(66.48)^{* * *}\end{array}$ & $\begin{array}{c}1083 \\
(37.56)^{* * *}\end{array}$ & $\begin{array}{c}47.8 \\
(46.16)^{* * *}\end{array}$ & $\begin{array}{c}277 \\
(2.74)^{* * *}\end{array}$ \\
Observations & 38926 & 65812 & 47108 & 13724 \\
$\mathrm{R}^{2}$ & 0.4 & 0.4 & 0.3 & 0.2 \\
\hline \hline
\end{tabular}

Notes: All regressions include annual time dummies and industry dummies and are estimated by OLS with White's correction of heteroskedasticity. t-statistics are in parentheses denoting $* * * 1 \%, * * 5 \%$, and $* 10 \%$ significance. Average wages calculated as total wages to total number of workers. Data in local currency, for Venezuela in thousands. See notes to tables $2 \mathrm{a}$ and $3 \mathrm{a}$ for definitions of the other variables. 


\section{Table 8a: Linkage effect - per Qualified Worker}

Dependent variable - Linkage coefficient, firm $I$

(Value of inputs bought domestically to qualified workers)

\begin{tabular}{lcc}
\hline \hline & Mexico & Venezuela \\
\hline Foreign & 14.8 & 1874 \\
& $(1.10)$ & $(0.43)$ \\
Observations & 46386 & 10439 \\
$\mathrm{R}^{2}$ & 0.1 & 0.1 \\
\hline
\end{tabular}

Notes: All regressions include annual time dummies and industry dummies and are estimated by OLS with White's correction of heteroskedasticity. $t$-statistics are in parentheses denoting $* * * 1 \%, * * 5 \%$, and $* 10 \%$ significance. Linkage coefficient calculated as inputs bought domestically to total number of qualified (or non production) workers. Data in local currency.

Table 8b: Intensity - per Qualified Worker

Dependent variable - Ratio of total inputs to number of qualified worker, firm $i$

\begin{tabular}{lcc}
\hline \hline & Mexico & Venezuela \\
\hline Foreign & 768.6 & 7614 \\
& $(4.98)^{* * *}$ & $(1.25)$ \\
Observations & 46018 & 10439 \\
$\mathrm{R}^{2}$ & 0.1 & 0.1 \\
\hline \hline
\end{tabular}

Notes: All regressions include annual time dummies and industry dummies and are estimated by OLS with White's correction of heteroskedasticity. t-statistics are in parentheses denoting $* * * 1 \%$, $* 5 \%$, and $* 10 \%$ significance. Intensity coefficient calculated as total inputs to total number of qualified workers. Data in local currency. 